Article

\title{
Corporate Sustainability and Green Innovation in an Emerging Economy-An Empirical Study in China
}

\author{
Shubo Liu ${ }^{1}$ and Min-Ren Yan ${ }^{2, *}$ \\ 1 Business School, Central University of Finance and Economics, Beijing 100083, China; liushubo@cufe.edu.cn \\ 2 Institute of International Business Administration, Chinese Culture University, Taipei City 106, \\ Taipei 24301, Taiwan \\ * Correspondence: mjyen@sce.pccu.edu.tw; Tel.: +886-227005858-8672
}

Received: 12 October 2018; Accepted: 28 October 2018; Published: 1 November 2018

check for updates

\begin{abstract}
Amid increased emphasis on sustainable development, understanding the sustainability initiative and practice of companies has attracted the attention of both academia and industry. Corporate sustainability combines triple values including environmental protection, social wellbeing, and economic benefit for companies. Drawing on institutional theory and employing an inductive case research method, we examine companies developing their green innovation and sustainability projects in a challenging context of China. Four representative case studies and in-depth interviews were conducted to examine how these firms overcome barriers in the less developed institutional environment. To better explain corporate sustainability with green innovations, a conceptual framework has been proposed to illustrate how firms operate in a network of relationship and cooperate with their external stakeholders. Firms' strategies to dynamically achieve the aim of corporate sustainability were identified based on a co-evolutional mechanism in the interface between institutions and organizations.
\end{abstract}

Keywords: corporate sustainability; green innovation; institutional theory; China; emerging economy; qualitative research

\section{Introduction}

Corporate sustainability is an approach that brings long-term stakeholder value. Such an approach implements a business strategy that integrates multiple dimensions including ethical, social, environmental, cultural, and economic spheres [1-5]. Such integrated perspective requires firms to adopt an open innovation approach and operate in a network of relationships-they must be open to collaborate with their stakeholders and external partners [6,7]. As corporate sustainability helps firms foster longevity [8-10], it has emerged as a top priority in their strategic thinking and innovation practices [11]. For instance, some companies have begun to measure their innovation projects based on environmental criteria $[8,12,13]$ and a growing number of green innovations, such as carbon-neutral plastic, e-waste recycling kiosks and an ethical smartphone, have proved profitable. In addition, companies that embrace green, environmentally friendly product design and packaging can improve their efficiency and differentiation advantages [14-18].

Corporate sustainability can bring about benefits such as reduced environmental impact, financial gains, enhanced corporate reputation, improved government relations, increased technology and innovation skills, increased risk-management skills, brand loyalty, employee commitment and ease of employee recruitment [8,19-24]. Corporate sustainability also presents a new source of ideas and visions leading to new business opportunities, or so-called "vision pull" [25-28]. Overall, they can enhance the long-run profitability of a firm. However, despite the benefits for both the firm and society, some progressive business practices such as environmentally friendly or green innovation may face 
institutional barriers in emerging economies because of the different and less supportive institutional environment $[29,30]$. For example, consumers from developing economies may be unaware of the environmental-friendly features of green innovation products and the local environmental protection system appears insufficient in supporting firms' green practice [31]. It can be expected that green innovation from corporate sustainability conception derived from matured Western markets might not be easily implanted into local contexts of emerging markets. In the other hand, it is seen that MNCs (multinational companies) operating in developing countries did not convert to the local lower standards, and firms operating in local context with "institutional voids" outperform to achieve sustainability development. How do we explain the manifestations of corporate sustainability in challenging or non-enabling institutional contexts? This puzzle remains unknown as there have been limited investigations on how firms achieve sustainability development in developing countries, with a specific focus on the presence and implications of institutional voids for corporate sustainability in these contexts.

Organizations can respond to the conditions and pressures of their embedded institutional context both in terms of economic efficiency and social legitimacy [30,32-36]. There are three distinct types of institutional forces both inside and outside of organizations: regulative, normative, and cultural-cognitive [37]. Firms' green innovation practices/projects derived from their corporate sustainability concern provide a window for examining the interaction of contextual factors and organizations' responses, and their proactive strategies for engaging various institutional forces.

Previous studies on corporate sustainability have focused on the relationship between influences, drivers and antecedents, and impact, competencies and consequences of sustainability practices and evaluated the criteria and effectuation of corporate sustainability [38-40]; other research on dynamics and processes of corporate sustainability has been mainly conducted in specific industries [41] or mature economics [39,42]. As corporate sustainability concerns stakeholders' expectations and implies improvements for multiple benefits, and the institutional environmental of developing economies differ from developed economies [29], it is attractive to investigate how firms learn to meet local customer expectations and manage to localize their green innovation products from initiative to practices in an emerging market context where institutions supporting sustainability are weak or largely deficient, i.e., where there are "institutional void" [29,43].

We take a qualitative approach to investigate the mechanisms of corporate strategic responses in their sustainability oriented green innovation projects as qualitative research is needed where the phenomenon under investigation is at a nascent stage [44,45]. China provide a good case study context as it is one of the largest emerging economies, and its institution supporting corporate sustainability is less developed. For example, although there has been an environmental protection system established by the Central Government, it is poorly implemented. The lagging institution facilitates irresponsible corporate behaviors and is averse to sustainability development. We then select projects from four companies that are pioneers and well representative in corporate sustainability practices in China. In doing so, this study builds on prior work [46-48] and contributes to the emerging literature on corporate sustainability and green innovation in the following ways: (1) examines the organizational context in which sustainability originates and documents the company organizational settings; (2) distinguishes the institutional context for corporate sustainability, especially the "institutional void" which pose both challenges and opportunities for companies developing their sustainability capability in emerging economies such as China; (3) identifies firms' strategic responses and the process of their localization practices of green innovation. Overall, this research seeks to answer the following question: "How do firms develop green innovations in a challenging institutional context vis-à-vis corporate sustainability?" To be more specific, we investigate firms' strategic responses to the institutional barriers during their development and launch of environmentally friendly products to China's market. This study finds that institutional barriers do exist, but that firms adopting sustainability can leverage the institutional void to develop a network which provides opportunities for their success in innovative projects. Moreover, "negotiation capability" plays a central role dealing 
with challenges and effectively recombining firms' resources to achieve a long-term goal. Research findings can help firms who are new entrants to the Chinese market to understand the specific Chinese institutional features regarding corporate sustainability, and provide suggestions for Chinese local firms to innovate environmentally friendly products.

The paper is structured as follows. In the next section, we review literature on corporate sustainability and green innovation, and grounds our work in institutional literature. Next, we outline our research methods and the data analysis procedures. Third, we present research findings. Lastly, we present discussions, contributions, and implications for research and practice.

\section{Theoretical Background}

Corporate sustainability has been a great interest in management literature. Sustainability is a social objective which focuses on achieving the triple bottom line performance: planet, people, and profit $[1,10,49]$. Corporate sustainability is defined as a process of companies creating shareholder value while considering all other stakeholders' expectations [50]. In this study, with an institutional perspective, we use the definition of corporate sustainability as a process of organization strategic responses to apply better solutions amidst external and internal contexts, in order to achieve stakeholder values [50]. The concept of corporate sustainability implies the integration of conservation of nature and more efficient use of resources, which requires firms to conduct green innovation. Green innovation (also known as eco-innovation) is defined as new products and processes which provide customers and business value but significantly decrease environmental impacts [51]. Similarly, Kemp and Pearson [52] p. 3 define green innovation as "the production, assimilation or exploitation of a product, production process, service or management or business method that is novel to the organization and which results, throughout its life cycle, in a reduction of environmental risk, pollution and other negative impacts of resources use compared to relevant alternatives". Suggested by Shrivastava, green innovation as corporate sustainability practice is focusing on both ecological and economical domains, and it should "consider full life cycle in production" and "set a new innovation/green standard to the firm".

According to the reviewed literature, corporate sustainability and green innovation need to be a multi-layered, context-embedded process with a complex configuration. Sustainability and green innovation expect firms to consider not only the economic benefit, but also the social impact of their practices [53]. Therefore, an openness and an innovation ecosystem of corporation is needed to seek ideas from outside partners, and to achieve reciprocal, responsive and respectful innovation outcomes [54-56]. Thus, we consider the institutional perspective to be an appropriate theoretical lens through which one can view the localization process of corporate sustainability, or the implementation of green innovation in an institutional context. Moreover, institutional theory has often been used by researchers to explain the responses of firms to pressures for sustainability [57-60].

In the institutional theory perspective, the corporate sustainability practices require certain conditions and institutional arrangements to function, such as strong government, market and civil society, and consumers' environmental protection awareness [31,61]. Therefore, it is assumed that strong institutional contexts put pressures on firms to engage in sustainability initiative, while sustainability practices are not likely to take place if these conditions and institutional arrangements are weak or absent [57]. The logic of institutional theory-based views is that corporate sustainability as well as corporate social responsibility in developing economies requires strong and effective market institutions; and thus, it is seemed that corporate sustainability would either not exist or would not be effective in developing economies. As in China, the institutional context bears adverse features for corporate environmentally responsible practices. This is because, firstly, in the political realm or regulative pillar of institutional environments, China did not experience a powerful and consistent environmental movement as did the U.S. and Europe [31]. Secondly, China's bourgeoning capitalism has not reached the stage of mass consumerism which has paved the road for green consumption in the West [62]. China's rapid economic development polarizes society into the 
poor and the rich. The poor, comprising most of the population, are still struggling to enhance their very low living standards. As users but not consumers, they seek to fulfil needs from commodities' functions. Although China's rising middle class is influenced by the imported environmentalism from the West through media and education, their green consumption for a green lifestyle is comparably in an early stage and their demand for expensive status-symbols such as green products is limited. The rich, on the other hand, can distinguish themselves by any conspicuous consumption and do not necessarily need to purchase green products to make themselves stand out. This condition of uneven economic development and social status has led to a lack of widely accepted norms on environmental protection and the general absence of the importance of environmental protection in the normative pillar, even though the environmental conditions are getting worse as a side effect of China's rapid economic development.

Additionally, the "pollution haven" hypothesis posits that when large industrialized nations seek to set up factories or offices abroad, they will always look for the cheapest option in terms of resources and labor that offers the land and material access they require, and this often comes at the cost of environmentally sound practices, as developing countries tend to have less stringent environmental regulations, lower environmental standards, and weaker enforcement [63]. According to the "pollution haven" hypothesis, firms from developed economies and operating in developing nations tend to localized towards local lower standards, instead of implant their higher home-country standards to the local contexts of developing economies.

The lens of previous studies with institutional theory tend to instill a sense of passivity into the phenomenon of corporate sustainability. That means social authorities will offer normative guidelines for, and impose regulatory constraints upon, organizations [64]. But this failed to explain the phenomenon of corporate sustainability practices that not only meet, but also exceed, local standards.

In comparison with the above "weak institution" assumption, the other "strong institution" views that firms have a significant agency to overcome institutional constraints. Put it another way, corporate sustainability can be seen as a corporate strategic choice [65]. Such an assumption of corporate agency provides a lens to explain corporate sustainability practices.

In this study, we investigate these often-neglected firms in the literature, which could be role models for corporate sustainability in China, and seek to identify the drivers of corporate sustainability and strategies employed. This quest is unique given that there could be more incentives for non-responsible (for environment) or non-sustainability business behaviors in such contexts.

Institutional pressure may affect organizations' approaches to their sustainability practices in many ways. Although regulating behaviors that affect sustainability development have historically produced positive results [66], it can also create problems. For example, research has shown that legal and taken-for-granted standards can become an independent force taking on a life of their own, leaving rationality, innovativeness, and societal interests behind [67]. Innovative sustainability practices, such as green innovation, may be stifled as decision makers become predisposed to select suboptimal over more optimal choices resulting from an adherence to regulatory standards. Moreover, institutional void may also negatively influence ventures' innovation through the means of guanxi exploitation and active government involvement [68].

Facing institutional pressure, firms will likely exercise their "strategic choices" [65,69]. More specifically, although firms exhibit certain signs of isomorphism, this may be done through choice, rather than as a need for legitimacy [43,70]. Berrone et al. [71] argue that institutional pressures may actually prompt heterogeneity rather than isomorphism in pollution-intensive industries when participating organizations engage in a "problematic search" to discover new pollution abatement methods. Moreover, Ahlstrom and colleagues find that in emerging economies where institutions are less developed, firms not only are in a passive position coping with rapidly changing and often chaotic environment, but can also proactively build legitimacy to enhance their long-term growth prospects $[29,30,72]$. Firms innovating for sustainability may find themselves pitted against existing institutional structures because the institutions or the firms often appear to lack legitimacy $[73,74]$. 
Although existing studies have investigated the institutional pressure and how organizations respond in their innovation projects [75,76], the focus of such studies is within internal organizational settings. Strategic responses to institutional pressures in their innovative practices towards sustainability have not been paid enough attention. Moreover, the process of how strategic responses and awareness emerge to resolve "legitimacy crises" in the sustainability development in an emerging economy context needs to be further investigated [77].

When firms behave in a strategically proactive manner, opportunity and interaction become central to innovative practices. Recent research suggests that opportunities are not pre-existing but rather are constructed "on the fly" [76,78]. In some situations, the institutional arrangements that support sustainability are weak or absent, and such absence or weakness is conceptualized as an "institutional void" [72,79-81]. This provides opportunities for innovating firms with sustainability initiatives to infuse new beliefs, norms and values into their immediate social structures. In responding to the institutional void, such firms will continuously interact with the external environment at the organization-environment interface to create opportunities $[30,75,77]$. In this way firms are therefore able to discover, create and enact opportunities to force changes in the existing order through a continuous process of interaction [82-86].

Big companies possess greater capabilities to alter institutional contexts. In many cases, multinational enterprises (MNEs) are as powerful as local institutional actors in some institutional contexts. Faced with a weak institutional environment-featuring an absence of accountability, lagging regulations, and poor enforcement of laws-the response of some MNEs, as well as some private local firms, is "co-opting" or "co-evolution" [29,31]. For example, MNEs operating in China actively engage in the formulation of environmental protection policies by developing requisite knowledge and technology and by attempting to influence policy-making [31]. In another example from Poisson-de and Bitektine's [42] study, firms from Spanish electric utilities are found to adopt diverse strategic responses in their corporate sustainability projects. In contrast to MNEs, small and medium enterprises (SMEs) are more likely to initiative green investments proactively rather than in response to institutions to enhance their sustainability innovation capability and green image [39].

\section{Methodology}

To investigate the dynamics of corporate sustainability and localization process of green innovation, we adopt an inductive, qualitative approach $[45,87,88]$. We employ iterative comparisons and systematic coding of critical episodes along innovation trajectories $[44,89,90]$.

\subsection{Research Design}

The analysis entailed four steps. In step one, based on the research of Carter and Mol [91] and Sinkule and Ortolano [92], we analyzed current state-level sustainability-related, political concepts, strategy and legislation in China (Table 1), this helped us to have a general idea of the regulative and normative environment of sustainability in this country. In the meanwhile, we conducted open interviews with government officials and industry experts on the topic of sustainability. These interviews took place in Beijing and Shanghai which are respectively China's political and economic centres. Three industrial experts from China Association of Urban Sustainable Development (CAUSD) and two governmental officials from Municipal Environmental Protection Office were interviewed during this stage. Existing research and policy makers/expertise' information helped us to narrow our research focus on certain industries: Fast Moving Consumer Good (FMCG), manufacturing, and real estate. These industries were chosen because they were developing fast and producing both prominent environmental and societal impacts in China. Moreover, such industries were better developed with more competitive market, and both multinationals and indigenous firms which integrated corporate sustainability into their strategy and practices can be identified. 
Table 1. State sustainability mandate.

\begin{tabular}{|c|c|c|c|}
\hline & Concrete Mandate & Pressure on Business & Business Opportunities \\
\hline $\begin{array}{l}\text { State-directed } \\
\text { Project }\end{array}$ & $\begin{array}{ll}\text { Key Forestry Programs (1998) } \\
\text { - } & \text { Natural Forest Conservation } \\
\text { - } & \text { Project (NFCP) } \\
\text { - } & \text { National Wetland Conservation } \\
& \text { programs (2002) } \\
\text { - } & 20 \text { key wetland } \\
\text { - } & \text { Sonservation projects } \\
\text { - } & \text { Corporation (2015) } \\
\text { - } & \text { Wind power industry investment } \\
\text { - } & \text { Solar power industry investment }\end{array}$ & 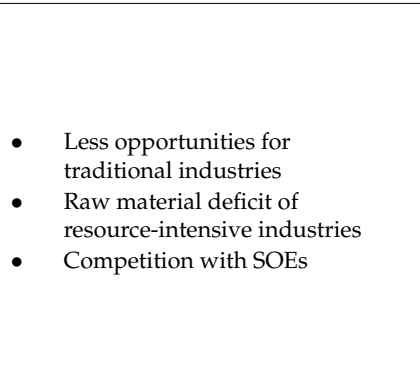 & $\begin{array}{ll}\text { - } & \text { Related product } \\
\text { demand boost } \\
\text { - } & \text { Infrastructure renovate } \\
\text { - } & \text { Clean energy } \\
\text { investment support } \\
\text { - } \quad \text { Systematic ecological project } \\
\text { cooperation opportunities } \\
\text { with central or } \\
\text { local government }\end{array}$ \\
\hline $\begin{array}{c}\text { State-Level } \\
\text { Political Concept } \\
\text { Development }\end{array}$ & $\begin{array}{l}\text { New Path of Industrialization (2002) } \\
\text { Scientific Development Concept (2003) } \\
\text { Circular Economy (2004) } \\
\text { Resource-economical and } \\
\text { Environment-friendly Society (2004) } \\
\text { Harmonious Society (2005) } \\
\text { Energy Saving and Emission } \\
\text { Reduction (2006) } \\
\text { Innovation-oriented Country (2006) } \\
\text { Ecological Civilization (2007) } \\
\text { Green and Low-carbon Economy (2009) } \\
\text { Transforming Economic Developing } \\
\text { Mode (2010) }\end{array}$ & $\begin{array}{l}\text { - } \begin{array}{l}\text { Expulsion of } \\
\text { resource-intensive/contamination } \\
\text { emission industries }\end{array} \\
\text { - } \quad \text { Higher human resources costs }\end{array}$ & $\begin{array}{l}\text { - } \begin{array}{l}\text { Demand boost by } \\
\text { government procurement in } \\
\text { green product }\end{array} \\
\text { - } \begin{array}{l}\text { Preferential policies for green } \\
\text { product from government }\end{array} \\
\text { - } \quad \begin{array}{l}\text { Financial support } \\
\text { by government }\end{array} \\
\text { - } \quad \begin{array}{l}\text { Sustainability } \\
\text { innovation encouragement }\end{array} \\
\text { - } \\
\text { Media exposure of } \\
\text { sustainability innovation }\end{array}$ \\
\hline $\begin{array}{l}\text { State-Directed } \\
\text { Strategy }\end{array}$ & $\begin{array}{l}\text { National Strategy of Sustainable } \\
\text { Development based on Energy Saving } \\
\text { and Emission Reduction (2010) } \\
\text { Transforming Economic Developing } \\
\text { Mode Strategy (2015) }\end{array}$ & $\begin{array}{l}\text { - Discriminatory treatment } \\
\text { against sunset industry } \\
\text { Expected competition in } \\
\text { green business }\end{array}$ & $\begin{array}{l}\text { Public private } \\
\text { partnership opportunities }\end{array}$ \\
\hline State Legislation & $\begin{array}{l}\text { Cleaner Production Promotion } \\
\text { Law (2002) } \\
\text { Environmental Impact Assessment } \\
\text { Law (2002) } \\
\text { Water Law (2002) } \\
\text { Renewable Energy Law (2005) } \\
\text { Energy Conservation Law } \\
\text { Amendment (2007) } \\
\text { National Climate Change Plan (2007) } \\
\text { Circular Economy Promotion } \\
\text { Law (2008) } \\
\text { Water Pollution Prevention Law } \\
\text { Amendment (2008) }\end{array}$ & $\begin{array}{l}\text { - Harsh punishment } \\
\text { for contamination } \\
\text { - } \text { Accelerated depreciation of } \\
\text { uneconomical equipment } \\
\text { - } \quad \text { Higher cost in raw } \\
\text { material processing } \\
\text { - } \quad \begin{array}{l}\text { Moral hazard of irresponsible } \\
\text { enterprise operation }\end{array} \\
\text { - } \\
\text { Media exposure of } \\
\text { non-eco-friendly } \\
\text { production mode }\end{array}$ & $\begin{array}{ll}\text { - } & \text { Regulated market } \\
\text { - } & \text { Fair competition }\end{array}$ \\
\hline
\end{tabular}

Source: The People's Republic of China National Report on Sustainable Development (2002-2015); The Chinese government website; Sustainable Development Strategy Study Group Chinese Academy of Sciences.

Following the selection of industries, we were able to further sample companies. Our sampling procedure is illustrated in Figure 1. In step two which started in the year of 2012 and last to 2016, we firstly identified accesses to 5-10 firms from each industry and conducted semi-structured interviews on the topic of corporate sustainability initiative and practice. Then, combining our interview data with secondary data such as company public reports on sustainability and corporate social responsibility (CSR), independent audit reports and company websites, we narrowed our sample firms to four: one leading firm from each industry was chosen. In step three, the investigation on corporate sustainability projects took place in which we conducted in-depth and face-to-face interviews with executives and relevant staff. The interviews took place within case companies headquarter offices in Shanghai and branch offices in Beijing from 2012 to 2017. We applied inductive analytic approach [87] and grounded theory (GT) [44] to systematically organize information obtained from interviews and secondary sources (Figure 2). With the outcome, we augmented our theoretical framework by refining each node in Figure 3. Additional interviews were arranged and supplementary secondary or documentary data were collected when necessary (Tables 2 and 3). In step four, we tested our theoretical framework under certain scenarios with an aim to further refine it. In the meantime, the latest literature in this realm was studied and organized to enable a comparison with our research findings. 


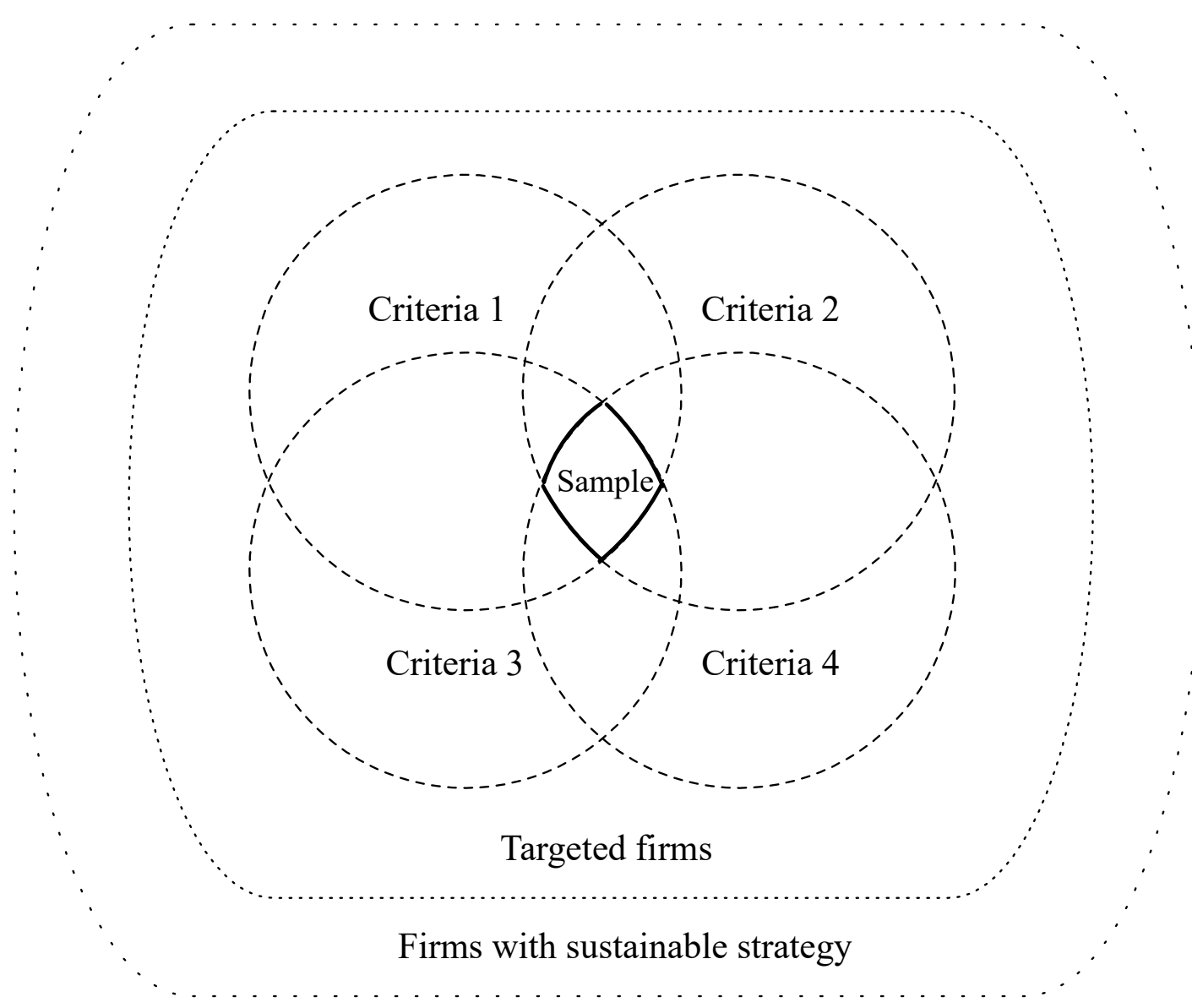

Figure 1. Sampling illustration.

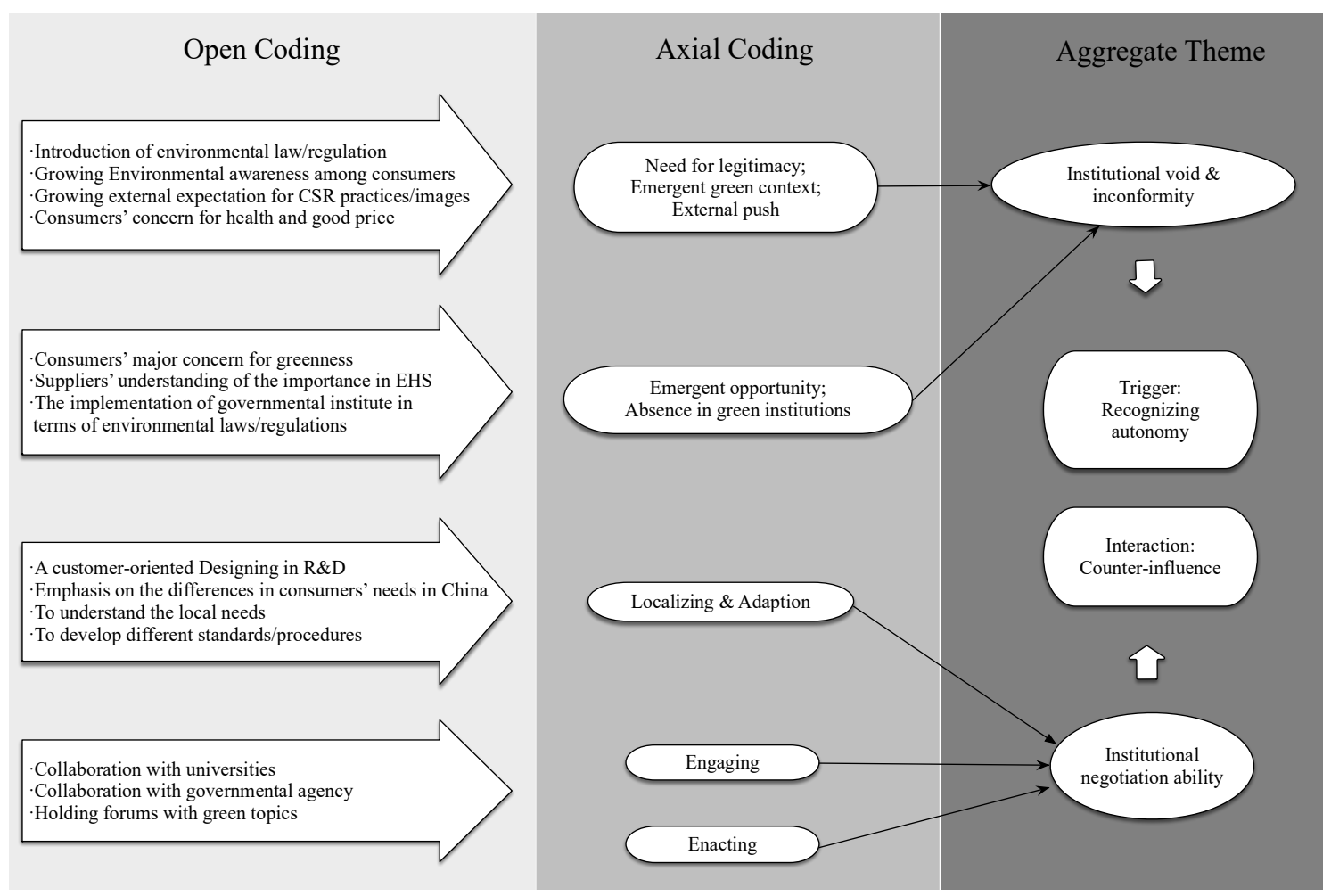

Figure 2. Grounded theory (GT) coding illustration. 


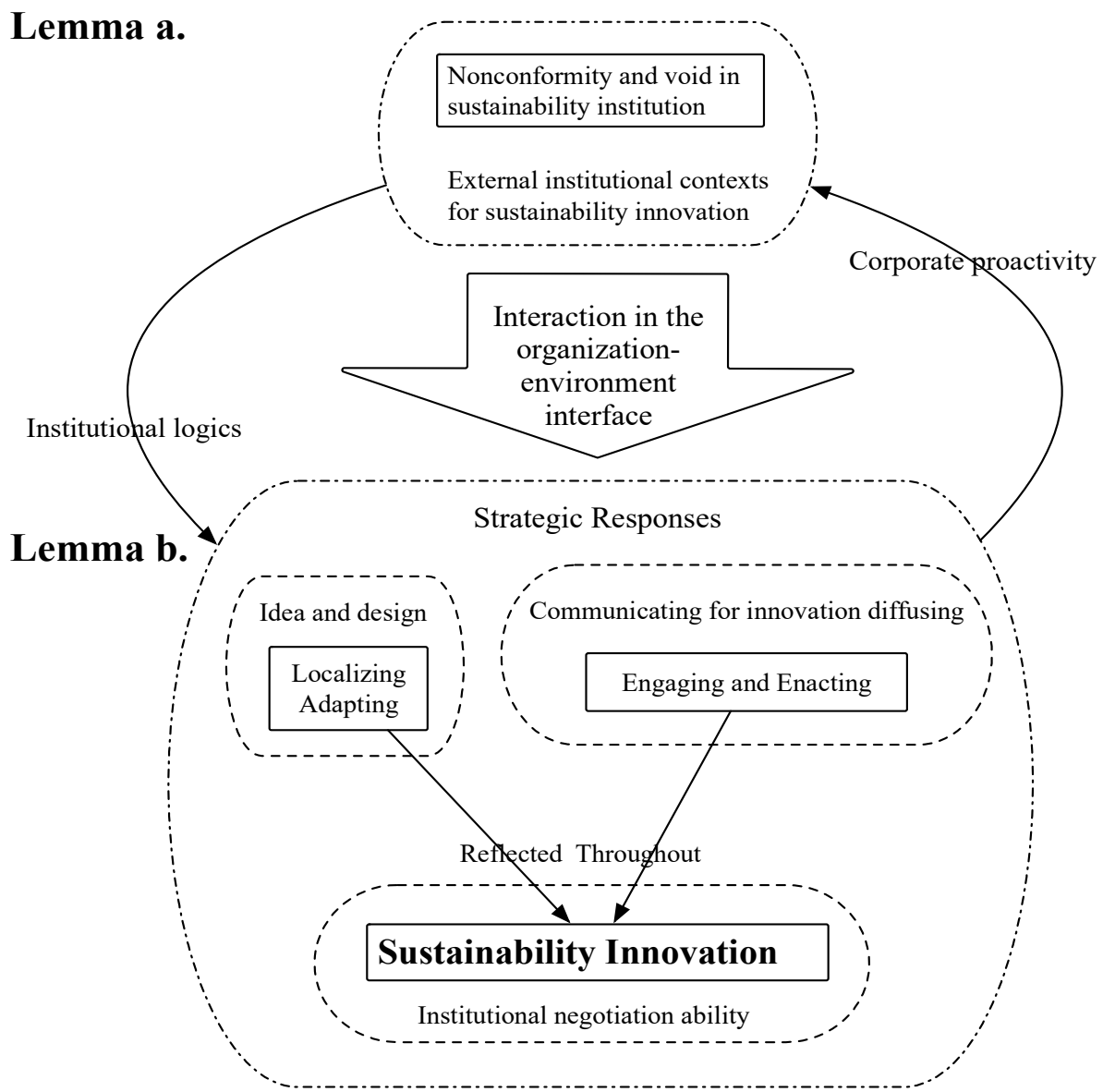

\section{Lemma c.}

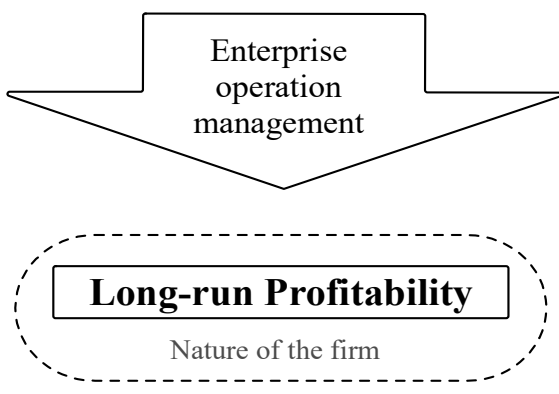

Figure 3. Framework of green innovation.

Table 2. Concrete company green innovation product/service/project.

\begin{tabular}{|c|c|c|}
\hline Companies & Sustainability Innovation Product/Service/Project & Main Objective \\
\hline \multirow{2}{*}{$\begin{array}{l}\text { Company A } \\
\text { (Philips) }\end{array}$} & EcoVision program & $\begin{array}{l}\text { - Include key performance indicators in relation } \\
\text { to Green Product sales } \\
\text { Improve people's lives, green innovation, } \\
\text { green operations, health and safety, employee } \\
\text { engagement and supplier sustainability. }\end{array}$ \\
\hline & The circular economy program & $\begin{array}{l}\text { - } \quad \text { Connect to stakeholders outside Philips } \\
\text { - } \quad \text { Internalize employee engagement } \\
\text { - } \quad \text { Create proof points and metrics } \\
\text { - } \quad \text { Embed circular economy in Philips processes }\end{array}$ \\
\hline
\end{tabular}


Table 2. Cont.

\begin{tabular}{|c|c|c|}
\hline Companies & Sustainability Innovation Product/Service/Project & Main Objective \\
\hline \multirow{3}{*}{$\begin{array}{l}\text { Company B } \\
\text { (Unilever) }\end{array}$} & $\begin{array}{l}\text { Unilever-Lipton Tea Lab } \\
\text { - } \quad \text { Catechin extraction } \\
\text { - } \quad \text { Tea related sustainable research }\end{array}$ & - $\quad$ Promoting sustainability innovation capacity \\
\hline & $\begin{array}{l}\text { The Unilever Sustainable Living Plan } \\
\text { - } \quad \text { Raw materials lean management } \\
\text { - } \quad \text { Reduce water use in manufacturing } \\
\text { - } \quad \text { Reduce GHG from manufacturing } \\
\text { - } \quad \text { Reduce waste from manufacturing }\end{array}$ & $\begin{array}{l}\text { Halve the environmental footprint of the } \\
\text { making and use of our products as the business } \\
\text { growth by } 2020 \text {. } \\
\text { - Help more than } 1 \text { billion people to improve } \\
\text { their health and well-being by } 2020 \text {. } \\
\text { - Enhance the livelihoods of millions of people } \\
\text { by } 2020 \text {. }\end{array}$ \\
\hline & $\begin{array}{l}\text { Unilever Food Solutions } \\
\text { - } \quad \text { Draft Food Safety Report of China annually } \\
\text { - } \quad \text { Healthy food recipe development } \\
\text { - } \quad \text { Health lifestyle propaganda } \\
\text { - } \quad \text { Catering industry consulting }\end{array}$ & $\begin{array}{l}\text { - } \quad \text { Root food healthy concept in market } \\
\text { - } \quad \text { timulate sub-brand food and ingredients } \\
\text { product consumption } \\
\text { Brand image promotion }\end{array}$ \\
\hline \multirow{3}{*}{$\begin{array}{l}\text { Company C } \\
\text { (Mary Kay) }\end{array}$} & $\begin{array}{l}\text { "Greening Office" project } \\
\text { - } \quad \text { Reduce } \\
\text { - } \quad \text { Recycle } \\
\text { - } \quad \text { Reuse }\end{array}$ & $\begin{array}{l}\text { - Reduce the negative environmental impacts of } \\
\text { administration activity }\end{array}$ \\
\hline & $\begin{array}{l}\text { "Greening Operation" project } \\
\text { - } \quad \text { Energy efficiency management } \\
\text { - } \quad \text { Waste management and recycling } \\
\text { - } \quad \text { Noise elimination }\end{array}$ & - $\quad$ Promote green core competences in producing \\
\hline & $\begin{array}{l}\text { "Greening Industrial Promotion" project } \\
\text { - } \quad \text { Greening purchasing } \\
\text { - } \quad \text { Eco-friendly product design } \\
\text { - } \quad \text { Low-carbon supply chain }\end{array}$ & $\begin{array}{l}\text { - Drive upstream and downstream into greening } \\
\text { innovation procedure }\end{array}$ \\
\hline \multirow{4}{*}{$\begin{array}{l}\text { Company D } \\
\text { (Landsea) }\end{array}$} & $\begin{array}{l}\text { Shanghai Green Fir Investment Co., Ltd. } \\
\text { - Invest in green real estate projects, green elderly } \\
\text { care industries, and energy-saving retro-fitting } \\
\text { projects of Landsea Group } \\
\text { - Invest in external profitable projects conforming to } \\
\text { the development direction of Landsea } \\
\text { - Carry out equity investment in well-run enterprises } \\
\text { relating to green industries and with the potential } \\
\text { to be listed }\end{array}$ & $\begin{array}{l}\text { - Improve the internal ability and } \\
\text { professionalization level for capital } \\
\text { operation further }\end{array}$ \\
\hline & $\begin{array}{l}\text { Shanghai Landsea Construction Si-tech Co., Ltd. } \\
\text { - } \quad \text { Green building design } \\
\text { - } \quad \text { Green building material research } \\
\text { - } \quad \text { Green building construction consulting }\end{array}$ & $\begin{array}{l}\text { - Improve the technological level of } \\
\text { green buildings } \\
\text { Reinforce leading position in greening } \\
\text { real estate }\end{array}$ \\
\hline & $\begin{array}{l}\text { Landsea Aged Care Investment Management Co., Ltd. } \\
\text { - 'Living with Parents' project } \\
\text { - } \quad \text { One Bowl of Soup' project }\end{array}$ & $\begin{array}{l}\text { Explore real estate projects and service systems } \\
\text { meeting the requirements of the } \\
\text { aged proactively } \\
\text { Build comprehensive functional aged care } \\
\text { communities, and the investment, development } \\
\text { and management of the aged care chain } \\
\text { service system }\end{array}$ \\
\hline & $\begin{array}{l}\text { Green real estate } \\
\text { - } \quad \text { Landsea Youth Block, Nanjing } \\
\text { - } \quad \text { Landsea Green Town, Taihu Lake, Suzhou } \\
\text { - } \quad \text { Landsea Future Block, Shanghai } \\
\text { - } \quad \text { Landsea Huamanli, Hangzhou }\end{array}$ & $\begin{array}{l}\text { - Upgrade from its single product line to multiple } \\
\text { product lines covering customers life cycles on } \\
\text { basis of its studies on customer demand }\end{array}$ \\
\hline
\end{tabular}

Source: Annual report of Philips (2012, 2013, 2014, 2015); Independent audit report of Philips (2014); Unilever website; Annual CSR report of Mary Kay (2011, 2012, 2013); Landsea website. 
Table 3. Nonconformity/Void examples and firms' responses in their green innovations.

Institutional Pillars

Exemplary Quotes

(A1-1) "China will stop imports and sales of incandescent lamps beginning with $100 \mathrm{~W}$ lamps from October 2012. This new policy means opportunities for our LED products and we are developing more innovations with LED technology." (Philips: Interviewee, A1, 2012)

(B1-1) "We aim to develop Green Products in these focal areas: energy efficiency, packaging, hazardous substances, weight, recycling and disposal and lifetime reliability ... the government wants us to be a good example in being green and we try to keep ahead in the field by our green products." (Unilever: Interviewee, B1, 2013)

the policies in China. And our manufacturing standards are always higher than the standards Chinese government set." (Mary Kay: Interviewee, C7, 2016)

(C7-2) "Our factory is based in Hangzhou, where laws are restrictive on water. So we set our waste water treatment standard at a high level, higher than national class-one wastewater-discharging standards." (Mary Kay: Interviewee, C7, 2016)

(D1-1) The advantage of differentiation is apparent. Of course we will face pressures. Being different means we are more likely to be recognized by society, clients, and the market .... What is surprising is when we win respect from our competitors in this market, of course, respect from government, media and other stakeholders." (Landsea: Interviewee, D1, 2015) as part-time professors in Universities." (Philips: Interviewee, A2, 2012)

(A3-1) "We organize a competition of entrepreneurship and R\&D among undergraduate students every year in China to help them understand the process of entrepreneurship and innovation." (Philips: Interviewee, A3, 2014)

(A4-1) "I have a full-time faculty job in Southeast University. I came to Philips because our linkage had been established when I was a PhD student in the Netherlands." (Philips: Interviewee, A4, 2014)

(A4-2) "Not only do my colleagues in the Health division cooperate with the hospital, our Lighting division does so as well." (Philips: Interviewee, A4, 2014)

(B3-1) "Some printing houses, they are our suppliers. When we visit them, we find that their printed materials always have scrap waste. They always have to expend more labor and other resources to treat the scrap ... Our staff always consume $3 \mathrm{M}$ stickers too much ... We designed booklets made with scrap ... This innovation can help us to reduce waste of our production and our office costs ... The booklet was a very distinctive present for our collaborators." (Unilever: Interviewee, B3, 2015)

(B1-2) "We encountered a bottleneck in propagation of green projects: the media will charge us a great amount of propagation fees, because they think they are propagating our brand. But in the UK, where I used to work, media are happy to cooperate with you when you have ideas and projects on greening and sustainability. They never ask for too much money when your concept is okay." (Unilever: Interviewee, B1, 2015)

(B2-1) “We invited the (U) of Wal-Mart Chin staff was high and they are all willing to push the sustainability process on all occasions." (Unilever: Interviewee, B2, 2015)

Normative (B2-2) "COFCO Group values cooperation with us ... Our standards and purchases made one of its small subsidiaries into one of the biggest tomato suppliers to the EU." (Unilever: Interviewee, B2, 2015)

(C7-3) “Our s2,

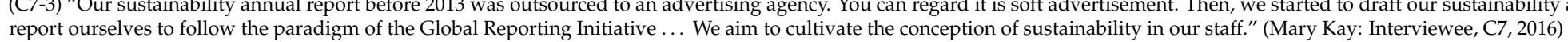
(C7-4) "We want to do cosmetics recycling, but there are no qualified Chinese enterprises able to do this thing." (Mary Kay: Interviewee, C7, 2016)

(C7-5) "Our factory in the US has specific partners in waste treatment. They draw energy from waste to generate electricity, and use the waste to produce cement. We failed to find such (C7-5) Our factory in the US has specific partners in waste treatment. They draw energy from waste to generate electricity, and use the waste to produce cement. We failed to find such China ... Our bio-degradable packaging supplier we cultivated in China was the first company able to produce $100 \%$ degradable packaging material in China. And we are also the first company in cosmetics using 100\% degradable packaging in China." (Mary Kay: Interviewee, C7, 2016)

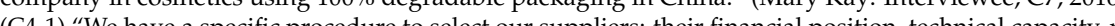

(C4-1) "We have a spscifert is mportant is their CSR. We will select suppliers who can reach our standards on environmental impacts." (Mary Kay: Interviewee, C4, 2014)

(C3-1) "We find our effect on the environmental protection movement is limited. So we focus on every step on our production links and office consumables. We cut off printed instruction booklets for our products, and print the instructions in the inner wall of our package. We spent more than one year to find a supplier that can produce $100 \%$ degradable material for packaging ... We spent another year to help them to improve equipment, redesign the production line ... " (Mary Kay: Interviewee, C3, 2014) 
Table 3. Cont.

\begin{tabular}{|c|c|}
\hline Institutional Pillars & Exemplary Quotes \\
\hline Normative & $\begin{array}{l}\text { (C7-6) "As Party A, we always have to face such risks: we can control the quality of our direct suppliers, but failed to control the quality of secondary or sub-level suppliers." (Mary Kay: } \\
\text { Interviewee, C7, 2016) } \\
\text { (C7-7) "The mindset of suppliers will change; they will gradually realize our requirements. One supplier who used to have CSR problems, they recently proposed an idea that the waste of } \\
\text { paper in the production procedure can be recycled to convert to school desks mixed with wood pulp and be donated to the school we sponsored in less developed places." (Mary Kay: } \\
\text { Interviewee, C7, 2016) } \\
\text { (C7-8) “We insist on localized procurement, though at first, as an international company, will account for the inconsistency problems between our standards and local suppliers' capacity. } \\
\text { We are more willing to cultivate our own suppliers .. D During our twenty years' cooperation with local suppliers, we gradually cultivated solid alliances in China." (Mary Kay: } \\
\text { Interviewee, C7, 2016) } \\
\text { (C7-9) "Now our suppliers are willing to join our CSR projects as non-business partners ... This year we aim to lead an alliance of our suppliers to do some philanthropic work together ... } \\
\text { Our operating strategies are also shared with our suppliers to inform our adjustment in operations so that they can do the same." (Mary Kay: Interviewee, C7, 2016) } \\
\text { (D2-1) "We organized our engineers to work with the Chinese Academy of Architecture, Shanghai Academy of Architecture, Tsinghua University in depth, and join green } \\
\text { architecture-related conferences, forums and activities via our projects." (Landsea: Interviewee, D2, 2015) }\end{array}$ \\
\hline Cognitive & 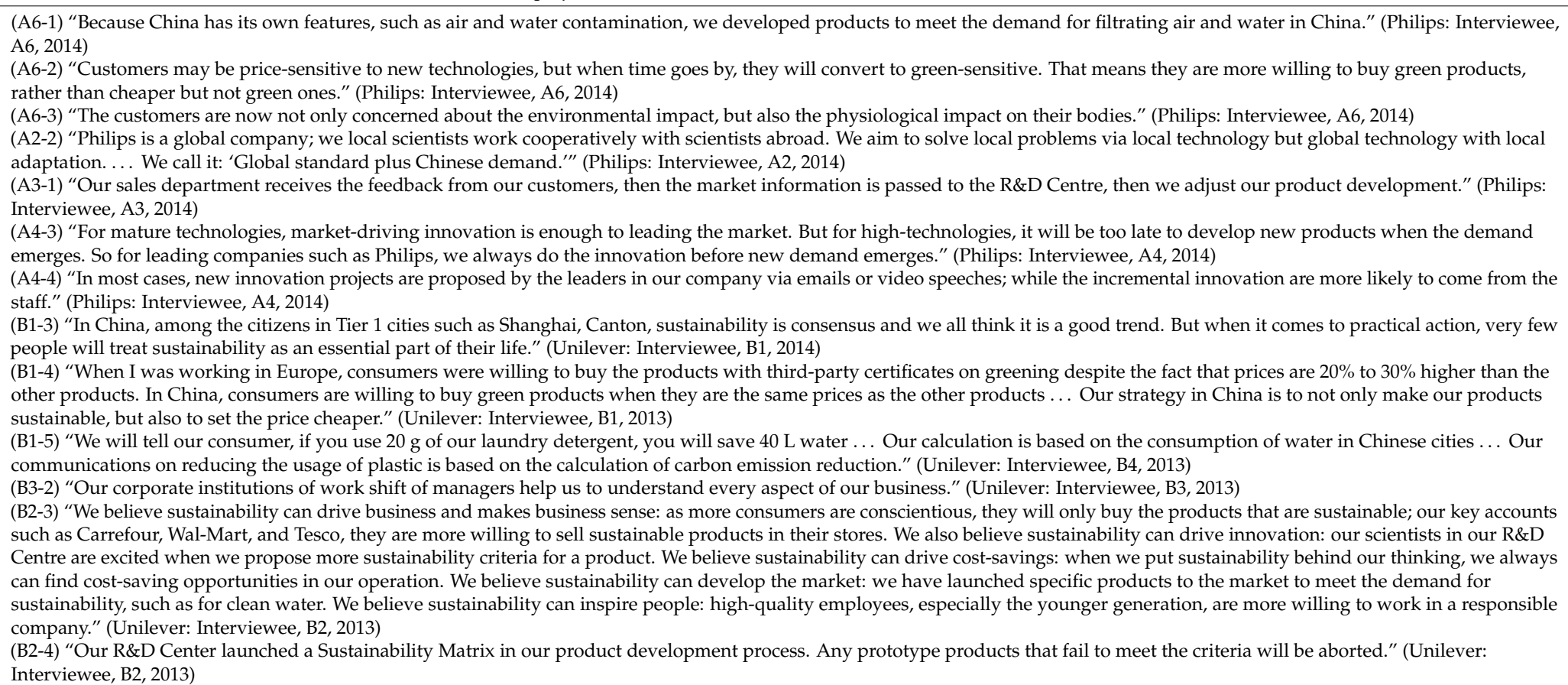 \\
\hline
\end{tabular}


Table 3. Cont.

(B2-5) “Leadership is the key understandable for all our staff and customers." (Unilever: Interviewee, B2, 2013)

(B2-6) “We formed a working group consisting of directors from different departments to exchange ideas for energy saving and emission reduction in all departments. We will call a meeting every two months to exchange our ideas." (Unilever: Interviewee, B2, 2013)

(B2-7) “We have an advisory board in China. Half of the members are our VPs and the other half are outside experts in sustainability. They will meet every six months. This is a key opportunity for us to educate our executives, instill the thought of sustainability. These experts are from Chinese Academy of Sciences, NGOs, independent research institutes, and top universities, with research interests in water, waste, and greenhouse gas emissions." (Unilever: Interviewee, B2, 2013)

(B2-8) "Our R\&D center in China is a global center, where two out of three staff members work for our global market, not the local market. Our innovation process involves four steps: define, discover, development and deploy. Define and discover is more like basic research. They cooperate with research institutions and universities closely with a global horizon. Development is a bit more narrow. They focus on regional markets such as Asia. Deploy is the most flexible step. They can adjust our product to the local market ... Our development is pure market oriented. The whole process from market to R\&D and back to market will be less than 18 months." (Unilever: Interviewee, B2, 2013)

(B3-3) “We launched a refill package for our products in plastic bottles in China. The plastic we use in plastic bags per milliliter of liquid is $30 \%$ of the plastic bottle ... The sales of this product increased $400 \%$ in the second year after its debut." (Unilever: Interviewee, B3, 2013)

(B2-9) “We stopped using leaflets and all other similar forms of propagating information in 2011. The change frequency of our printed poster was reduced from once every two months to twice a year." (Unilever: Interviewee, B2, 2013)

(C7-10) “In the past, the strategic management and sustainability innovation all depended on our management team. But when we turned to our staff, they had more detailed suggestions for our projects from the community, products for customer relations ... And our experience will be shared with our global peers, especially the companies in small markets in Asia." (Interviewee, C7, 2016) (C7-11) "Recently, our project team members began to be cross-hierarchy: one typical team consists our CEO in Greater China, our VPs, and newly recruited staff. Such team members bring different ideas and thinking modes." (Interviewee, C7, 2016)

Cognitive (D1-2) “We learn fast: we buy products from OEMs directly to reduce our costs. And we always can find replacement products with the same or similar function for lower prices. We want to localize our technology." (Landsea: Interviewee, D1, 2012)

(D1-3) "Among all the Chinese real estate companies, we are relatively similar, but we have more engineers focused on fan heaters and energy. We do have our own characteristics and advantages, but if we merely focus on the advantage we have and neglect the basic demands of our customers, our products will not be competitive ... Due to our initial immaturity, we failed meet the basic requirements of our customers, and paid too much attention on our greening innovation. Now we work to meet the basic requirements of consumers and then add our unique green technology." (Landsea: Interviewee, D1, 2012)

(D1-4) "For the climate of China, every city has its own local climate, which is the basis on which we design our product. Another key factor we have to take into consideration is the local culture.

We will not copy our benchmarks from the EU: it is infeasible, and the cost is also too high." (Landsea: Interviewee, D1, 2012)
(D1-5) "Innovation relies on the interaction between people and the market. I do not think R\&D without involving clients and the market will succeed.... We have the policy of work shift: we will send our engineers to market positions, costumer relation positions ... This is good for personal and organizational development." (Landsea: Interviewee, D1, 2012)

(D2-2) “Unlike other real estate developers, Landsea Group has strong capabilities and rich experience in value chain management covering the green building business. Landsea Group has its own property companies and own design institutes, and therefore it has control over the entire process from preliminary concepts to construction and property management." (Landsea: Interviewee, D2, 2015)

(D2-3) “Since the introduction of green products, Landsea Group has been carrying out detailed assessments on diverse aspects, such as the light environment, wind environment, building thermal design, noise reduction and water conservation measures." (Landsea: Interviewee, D2, 2015)

(D2-4) “Landsea Group adopted a differentiation strategy to gain a favorable market position in the real estate industry. Sustainability is the core element of its differentiation strategy. The senior management on the board participated in the strategic planning and implementation." (Landsea: Interviewee, D2, 2015)

(D2-5) "When setting" corporate environmental targets, Landsea Technology conducts surveys and analyses and sets long, medium and short-term targets, and decisions are made by the chairman's office; at the stage of product R\&D, Landsea Technology studies environmental affairs and submits indexes and plans, and the chairman's office meeting makes decisions; at the stage of project investment, the investment department collects environmental information, and Landsea Technology reviews the information and the investment committee makes decisions; at the stage of project development, Landsea Technology reviews environmental indexes and the president's office makes decisions." (Landsea: Interviewee, D2, 2015)

(D2-6) “Landsea Group is the editor in chief of the Design Code for Interior Air Quality Control of Public Buildings, and it co-edited the Radiant Panel Heat Exchangers for Cooling and Heating, Vacuum Insulation Panel for Buildings, Technical Code for Green Building Operation Maintenance and Technical Rules for Evaluation of Green Aging Communities." (Landsea: Interviewee, D2, 2015)

(D2-7) “Landsea has joined the UNEP Climate Neutral Network, the Climate Group and the China Green Building Council, co-initiated the 'China Home's Alliance of Low-carbon Development,' and been committed to exploring a resource-conserving and environmentally-friendly path of high-benefit development. Landsea has won a collection of top green building awards such as the Elite Gold Award for Housing Science and Technology' from the Ministry of Science and Technology, the 'Huaxia Building Science and Technology Award (First Prize)' from the Ministry of Housing and Urban-Rural Development, the 'Green Asia Habitat Award' and the 'Three-Star Label for Green Building Design.'”' (Landsea: Interviewee, D2, 2015) 


\subsection{Data Reduction and Analytical Approach}

To build a guiding framework for exploratory research, we consulted executives and experts in our targeted industries in conjunction with relevant information and other relevant contacts. Next, we purposefully used a sampling technique based on theoretical sampling logic to generate samples for the study. We sampled our case intentionally using a theoretical sampling logic [93-95]. More specifically, the sampling procedure was as follows:

To begin our research, open interviews with representatives of industrial associations and public institutions were conducted. The interviews were used to develop a scenario on firm-level sustainability issues and opportunities in this field as informed by expert opinion on the sustainability practices of firms. This is shown in the outermost circle in Figure 1. Multiple factors, such as region, secondary data availability, production capacity, etc., were comprehensively considered. Integrated with our investigation of sustainability-related products and innovation practices, we then narrowed our preliminary screened samples to create our targeted firms in Figure 1. We then consulted with industrial associations and explored secondary data sources, such as company annual reports, CSR reports, and independent audit reports on sustainability. Based on this, 26 companies from Beijing and Shanghai were found to be incorporating sustainability issues in their products (in the inner four circles in Figure 1). To dig deeper into firms' strategic responses in their sustainability and green innovation projects, four criteria were developed based on pilot studies and literature [93,94]. The framework helped us to further select our samples: (1) The company should have a series of green and socially beneficial products, i.e., products that were communicated as having environmental protection features, such as pollution reduction or energy efficiency enhancements. (2) The firm should operate in one of the natural-resource-intensive industries that have seen the greatest pressure to improve their environmental impact. (3) The company should have a strong environmental and social performance in the context of its industry and have been rated among the top green or socially responsible firms in China for consecutive years (from 2012-2016) according to China's Green Company rating (China Entrepreneur Club). (4) The firm's sustainability-related product and service innovations should be profitable and thus considered to be successful in the market. Through this screening mechanism, three renowned MNCs and one local Chinese firm (Table 4) were selected as the final sample: Philips, Unilever, Mary Kay, and Landsea. Specific green innovation projects were identified referring to definitions and criteria from literature. There are in total 7 green innovation projects investigated from case companies, an average number of 7 in-depth interviews were conducted within each company (Table 4). Each interview lasted from 50 to $90 \mathrm{~min}$, in total about $30 \mathrm{~h}$ interviews were transcribed into data.

Through both face-to-face in-depth interviews and focus groups, we gained an understanding of key actors' and stakeholders' perceptions of sustainability and their manifestation in different projects. In addition, company records and published primary and secondary data were studied for triangulation [89].

Initially, we were interested in how firms respond to opportunities and challenges amidst growing concern for development of sustainable/green business practices. Existing literature suggested that such processes could be context specific. We conducted exploratory pilot interviews to better comprehend the institutional environment for development of sustainability practices in the Chinese market. We interviewed four prominent corporate leaders and consulted three industry experts to obtain their perspectives on the development of corporate sustainability and CSR practices in China. These interviews were purposely broad in scope and touched on topics such as motivations behind sustainability-related efforts, limitations of resources and governmental regulations, market potential, and organizational innovation procedures. During these interviews with industrial leaders and experts, the contour of institution (e.g., regulative system of environmental protection and industrial standards/norms) supporting sustainability development in China emerged. Following interviews with employees and decision makers from case companies helped us to identify the notions of non-conformity and voids in institutions that influence firms' sustainability-related practices, and find 
out the corresponding corporate strategic responses. These findings lead us to investigate such aspects with further interviews. In order to enrich our understanding of the innovation and localization processes, we conducted formal interviews in Chinese, which were recorded, transcribed, translated, coded and analyzed with the support of Nvivo [45]. During the analytical process, we conducted open coding and axial coding, and aggregated themes surrounding an interactive innovation process (Figure 2). The key findings are presented in the following section.

Table 4. Companies and their green innovation projects.

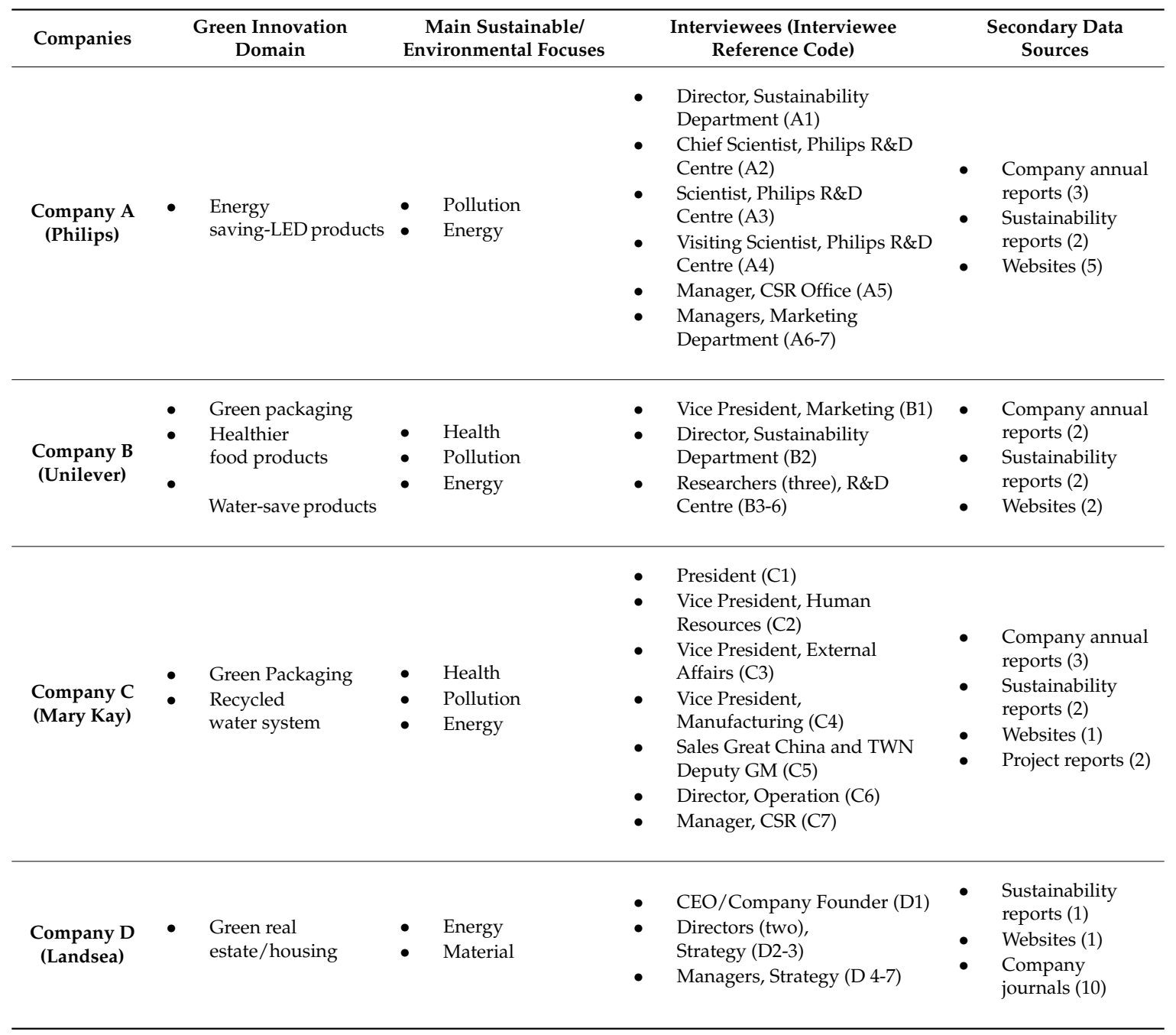

\section{Findings}

The data analyzed is from four case firms: Philips, Unilever, Mary Kay, and Landsea. Below is a brief introduction to the firms regarding their operations and sustainability practices.

Koninklijke Philips N.V. (commonly known as Philips) is a Dutch technology company consisting of three main divisions: Philips Consumer Lifestyle, Philips Healthcare and Philips Lighting. The company was one of the earliest foreign-funded enterprises to enter China after the Reform and Open Policy. The R\&D Centre it opened in Shanghai in 2005 represented the shift of its strategic priorities from Europe to China. Philips has a fine tradition of innovation since the early 20th century. The sales volume (proportion) of green products among all three divisions of Philips jumped from $6899(35.8 \%)$ to 11,065 (51.7\%) million Euros between 2010 and 2014, symbolizing its intensive focus on sustainability-related innovation. 
Unilever, an Anglo-Dutch multinational consumer goods company with over 400 brands in food, beverages, cleaning and personal care, has the third-largest share of the global fast-moving consumer goods (FMCG) industry after Procter \& Gamble and Nestlé. Unilever entered China in 1986 through a joint venture with two local state-owned consumers goods companies. (Unilever's predecessor, Lever Brothers, produced soap in China as early as the 1930s.). Its sixth R\&D Center was opened in Shanghai in 2000 with more than 450 researchers from 15 countries. In 2004, Unilever opened its China headquarters in Shanghai.

Mary Kay Inc., an American private direct sales company in cosmetics products, entered China and set up its branch in Shanghai in 1995 after its commercial success in the U.S. Before 1995, its primary manufacturing plant was located in Dallas, Texas; it later opened its second plant in Hangzhou, Zhejiang. This plant with eco-standards was enlarged in 2006 to meet its rapid sales growth in Greater China, and its administrative center was opened the following year in Shanghai. The fast growth of Mary Kay, with over 474,000 saleswomen and a market share of 5\% at the end of 2014 in China, resulted in large part from its deep anchor in the Chinese market.

Landsea Group, established in 2001, is a real estate company regarded as the leading developer and operator of green tech properties in China. Landsea developed more than 50 projects in major Chinese cities on the country's east coast. Residences developed by Landsea were designed to be healthy, environmentally-friendly, comfortable and energy-efficient. It is a typical example of domestic company that has accorded importance to sustainability innovation.

Studied green innovation projects, products and services of the four case firms are categorized in Table 2. In Table 3, we have systematically listed firms' responses and quotations to illustrate examples of institutional barriers.

\subsection{External Institutional Contexts for Corporate Sustainability}

In presenting findings from studies on these firms, we first consider the influential forces from institutions and then consider the firms' responses and interactions during their sustainability projects processes. Sustainability initiatives were identified within the four case firms. Our findings reveal that it is necessary to overcome barriers from China's institutional environment in order to implement the sustainability initiatives in the sustainability development process. We posit our findings around three broad themes identified during our analysis: (1) External "push"; (2) Institutional nonconformity; and (3) Institutional void.

\subsubsection{External "Push"}

External "push" factors refer to both positive and negative aspects of the institutional context that encourage the development of corporate sustainability-related practices. The external push represents the conformity where new sustainability ideas/products are adapted to be consistent with established interests, norms and beliefs in the institutional environment.

China has experienced a fast pace of economic growth, with a substantial inflow of foreign direct investment. Corporate sustainability has gained traction since the 1990s, during the early stages of environmentalism in China. At that time, the authorities in China pursued a flexible system of regulation that relied on fines rather than on quantitative restrictions. This is because the government feared that tough pollution penalties might jeopardize economic growth and jobs [31,96,97]. However, a surge in environmental scandals-a consequence of China's being treated as a "Pollution Haven" [31], especially by companies from Hong Kong, Macao and Taiwan [98] — has raised the attention of the Chinese government as well as academia. The government began to focus on industrial upgrades, innovation and green technologies, especially in radical innovation [48]. As Table 1 demonstrates, sustainability-related political concepts proposed by the Communist Party of China (CPC) have been frequently presented in the National People's Congress (NPC), the top of the power structure according to Chinese Constitutional Law, in the last 10 years. The state mandates in Table 1 represent both positive and negative influences of the institutional context on business. 
Currently, China is raising the market-entry threshold for high energy-consuming industries and has capped or even shut down heavy polluting companies. China's latest Five-Year Economic Plan, i.e., The Thirteenth Five-Year Plan, proposed in March 2016, targets "sustainable mode of production processes: transform the traditional unsustainable manufacturing mode into clean mode; build a green industrial system: upgrade the production facility, construct a green financial system especially the green fund; amend the environment Protection Law" (Table 1).

Government policy is always a key factor affecting a firm's policy. A typical example is illustrated in Landsea's successful differentiation strategies, which were developed in response to government policies (Table 3, quote D1-1). In 2012, politically sensitive Landsea launched its green financial program, a wholly-owned subsidiary of Landsea Group called Shanghai Green Fir Investment Co., Ltd. (Shanghai, China), which aimed to invest in green real estate projects, green elderly care industries, and energy-saving retrofitting projects (Table 2). Historically, China has been a country dominated by government institutions, and this institutional phenomenon largely remains unchanged; thus, the government's attitudes translate into demand and opportunities (Table 3, quotes A1-1, B1-1). Because it has been too risky for enterprises, especially foreign-funded ones, to cross the red line of the Chinese government, they erred on the conservative side in terms of reacting to government policy (Table 3, quotes A7-1, A7-2).

Landsea's strategy is consistent with the business opportunities illustrated in Table 1: demand would increase with the government's procurement of green products. Although the government has turned its attention towards sustainability, supporting institutions for sustainability are still largely absent. Laws, policies, and regulations play the dominant role, while other external factors, such as culture, customers and the market, have much less impact.

\subsubsection{Institutional Nonconformity}

We define "institutional nonconformity" as the mismatch between expectations derived from external institutions and the standards driving the internal green innovation process. Institutional nonconformity is different from institutional void in ways that it refers both to lower or higher standards. Put it another way, nonconformity forms both an institutional constraint (institutional void) and an institutional push for corporate sustainability development. It is a constraint in the sense that the external sustainability standards are lower than the corporate internal ones; conversely, it exerts push on the firm for improving its sustainability practices. The motivating pressure of institutional nonconformity for sustainability development comes mainly from the government, i.e., regulatory pillars of institutions [37]. In China, the Communist Party of China (CPC) plays an essential and dominant role in the construction of regulatory pillars to guide industries' development of sustainability practices. Thus, companies conducting sustainability projects must devote much attention to government policies and regulations regarding environmental protection and sustainability.

On the other hand, regulative nonconformity could also produce constraints to corporate sustainability development. For example, the Chinese LEED (Leadership in Energy and Environmental Design Building Rating System) standards have not been updated for years, and efforts to innovate more sustainable products often become protracted political battles that result in suboptimal compromise. In another example from the building industry, innovative and improved changes in green housing have been resisted because firms habitually use old designs that satisfactorily meet the prevailing regulatory standards. Firms prefer the status quo regulations rather than adopting more innovative designs. Nonconformity constraints are also found in consumers' perception of green innovation products. For example, some environmentally friendly features of products are considered incompatible with the norms of people's cognition and thus create resistance because they lacked cultural legitimacy (Table 3, quotes B1-2, B1-3, B1-4). 


\subsubsection{Institutional Void}

Regulatory pillars established by the Central Government are not the only institutional pillars. Normative and cognitive pillars can also impose constraints on corporate sustainability development. The absence of sustainability dynamics in the normative and cognitive pillars can also drive nonconformity. Specifically, such nonconformity is termed "institutional void."

There have been many barriers to sustainable development in China: an inadequate social security system for a growing population of elderly people, structural unemployment, an irrational economic structure, underdeveloped infrastructure, large-scale exploitation of natural resources, non-recycling, environmental pollution, etc. Despite the fact that China has been rapidly promulgating new laws and policies (Table 1), the combination of rapid legal enactment with multiple overlapping layers of jurisdiction can create considerable uncertainty. Moreover, the opaque nature of the institutions in terms of their complexity and arbitrariness have often served economic rather than environmental aims [31].

Lack of accepted norms means that firms wishing to initiate green innovation projects must work with suppliers that may not share the same concerns for sustainability. For example, Mary Kay planned to replace environmentally harmful plastic packing foam with recyclable bio-foam (Table 3, quote C7-5). However, because local suppliers of qualified recycled packaging products are difficult to find, Mary Kay has to invite suppliers from the U.S. to China, and then spend two years cultivating a local supplier (Table 3, quotes C7-5 and C3-1). For some other sustainability-related projects that work well in the U.S., such as cosmetics recycling, no qualified suppliers could be found in China (Table 3, quote C7-4). Moral hazard is inevitable when a company occupies the central spot of a supply network (Table 3, quote C7-6).

This institutional pressure poses challenges for corporate sustainability development, and is an example of institutional constraints that must be overcome. However, by spotting and responding to these institutional pressures, firms may exploit them for business opportunities with green innovation products. We find firms pursuing green innovations that are proactively overcoming institutional pressures. Their strategies can be broadly categorized as localizing and adapting in innovation design, engaging for allies' support, and enacting new industrial norms and standards with collaborators.

\subsection{Firms' Strategic Responses}

\subsubsection{Localizing and Adapting}

Localizing and adapting is a regular strategic response by which organizations adjust themselves to local business settings. Being sustainable means integrating environmental and social responsibilities into company strategy at the firm level. For MNEs, the business setting in China is unique, and requires efforts to adapt to the local market. Also, different regions in China are at different stages of social development, and individuals' lifestyles, culture, and population structure are heterogeneous geographically across the country. We find that our sample firms are localizing their sustainability projects by learning and addressing local factors, such as geographic, cultural, and technological and societal differences, and developing localized green innovation products.

A typical company differentiating via localization is Landsea, which, after some early setbacks (Table 3, quote D1-3), has been able to occupy a preeminent position in the real estate industry by adapting itself to local markets and localizing green technologies from the EU (Table 3, quotes D1-2 and D1-4). This trial and error process has taught Landsea how to allocate its resources through a localization strategy. The company recently opened a wholly-owned subsidiary company, called Shanghai Landsea Construction Si-tech Co., Ltd. (Shanghai, China), specialized in green housing design and eco-friendly building material development; it can also provide consulting services to construction firms seeking to build green housing or large public buildings (Table 3, quote D2-2). The subsidiary can help Landsea acquire localized building material as well as access tax abatements. Its strategy follows trends in the Chinese market. For example, to tackle the increasing population of 
elderly people, it launches a Confucian-oriented 'Living with Parents' project and 'One Bowl of Soup' project to raise consumers' awareness of the importance of treating elders and parents with honor. Concretely, to enable two or more generations to live together but with independent spaces, Landsea has modified its spatial design and expanded the adaptability and flexibility of the housing space in combination with its core greening technologies.

Localizing and adapting is a dynamic process of responding to changes in local markets. China itself is undergoing a dramatic evolutionary development process, and the mindset of its citizens is geographically and inter-generationally heterogeneous. For a leading company such as Philips, an intelligent localizing and adapting strategy should be adjusted not only by location (Table 3, quote A6-1), but also by period, even by the life-cycle of a new technology (Table 3, quotes A6-2, A6-3). For another example, Unilever illustrates the benefit consumers gain when using Unilever's product (Table 3, quote B1-5). To capture the latest information from the market and translate it into R\&D activities, Philips uses a negative feedback mechanism to drive innovation in mature markets (Table 3 , quote A3-1). Given how quickly market conditions and demand trends can change, new technologies must traverse the established innovation path (from basic research to application) relatively quickly to avoid being outdated by the time of commercial launch (Table 3, quote A4-3). As a leading company, Philips's strategic structure for innovation combines its global basic research capabilities with localized applied research in China (Table 3, quote A2-2). Although this leading FMCG company has its own basic research centre and localized research capabilities, which allow it to adapt products to local markets relatively quickly, the lifespan of innovations in the FMCG industry is short relative to other sectors (Table 3, quote B2-8).

\subsubsection{Engaging and Enacting}

Engaging is an intermediate strategic response for organizations to connect their recourses, technologies, brands, etc. with networks in the environment. Engaging means cooperating with stakeholders, including internal (e.g., employees, managers, and owners) and external (e.g., shareholders, customers, and the environment) [99]. Just as innovation processes commonly involve a dialogue among the innovating firms and a variety of stakeholders [100], so does the process of corporate sustainability development.

Furthermore, enacting is an advanced strategic response of organizations, when one organization gains enough influence in a regional market or on a global scale and intends to modify or even dominate the whole industrial chain or a certain sector. Enacting involves establishment of new norms or rules towards sustainability practices. In reality, the multiple factors that influence strategic decisions make it hard to classify one strategy as engaging or enacting.

Corporate sustainability refers not only to innovative practices that bring profits and benefits to companies but also to other stakeholders. Thus, corporate sustainability development projects must take a number of factors into consideration during initiation, design, implementation, and application. Through collaborations with stakeholders, firms are better able to embed sustainability into their business operations. The concept of organizational learning stresses the influence of internal communications and project work, multi-stakeholder dialogues, partnerships, etc. as critical mechanisms for fostering successful sustainability development projects [101,102]. In order to collaborate with stakeholders, all companies in this study have established multiple relationships with local stakeholders.

These relationships with local stakeholders often give domestic firms an advantage over foreign multinationals in dealing with local institutional void because of their experience, cultural familiarity, and local network spread. Companies with basic research centres in China are better able to closely cooperate with local research institutions. Normally, they cooperate with universities, academies and hospitals on a project-by-project basis (Table 3, quotes A4-2, B2-8, D2-1). Philips has a more profound interaction with local research institutions: the company hires scientists from local universities (Table 3 , quote A4-1) and encourages its own full-time scientists to join universities as part-time faculty 
(Table 3, quote A2-1). To further engage the community, Philips organizes entrepreneurship and R\&D competitions for undergraduate students (Table 3, quote A3-1).

Engaging with suppliers and retailers is an essential strategy for FMCG companies, especially if their understanding of sustainability is inconsistent. Mary Kay, for instance, selects suppliers not only based on economic characteristics, but also on ecological values (Table 3, quote C4-1). In addition, Mary Kay has spent more than 20 years cultivating its suppliers in China, including instilling them with sustainable ideas (Table 3, quotes C7-7, C7-8, C7-9). Unilever has had similar experiences (Table 3, quote B3-2) in building up its small suppliers' sustainability and green performance. Notably, both of them win respect when their guidance on sustainability and bulk-buying leads to the development of new companies (Table 3, quote B2-2). Additionally, they frequently engage their direct customers, i.e., the retailers (Table 3, quote B2-1).

A strategy of engaging not only means engaging stakeholders outside the company, but also those inside the company. To cultivate the concept of sustainability among its employees and saleswomen, Mary Kay transformed its sustainability annual report from a soft advertisement into a readable report rich in data and case studies (Table 3, quote C7-3). Once Mary Kay cultivates the concept of sustainability internally, its staff becomes creative in this area (Table 3, quote C7-10), leading to organizational innovations inside the company (Table 3, quote C7-11). Common engagement strategies within companies include work-shift policies and programs aimed at enriching employees' outside experiences to incentivize innovation (Table 3, quotes B3-1, D1-5) and other forms of innovation creation via inside meetings (Table 3, quote B2-6), advisory boards (Table 3, quote B2-7), and leadership engagement (Table 3, quotes A4-4, B2-5, D2-4, D2-5). Once employees find that they can manage internal improvements, the engagement process inside the company can also stimulate sustainability-related improvements in manufacturing and other areas (Tables 2 and 3, quote C3-1).

Besides educating suppliers through cooperation, the firms in our study also actively engage in industry programs at the national, regional and global level to help the industry as a whole bring about changes towards sustainability. Globally, Unilever dominates the Consumer Goods Forum (CGF), which is an industry association that brings together over 400 retailers, manufacturers, service providers and other stakeholders across 70 countries. Nationally, Landsea is a contributor of some journals related to real estate in the editorial board (Table 3, quote D2-6). To gain more influence and reinforce its greening strategy, Landsea joins industry associations such as the UNEP Climate Neutral Network, the Climate Group and the China Green Building Council; this active engagement has helped Landsea win influential official prizes (Table 3, quote D2-7). Engaging with research institutions or industry associations can also boost the professional image of a brand. Responding to food safety issues in mainland China, Unilever transplanted its Unilever Food Solutions to China with localized adjustments. Implemented through its food and ingredient brands in China, this project aims to raise awareness among consumers and retailers about food safety and healthy eating habits. Collaborating with the China Cuisine Association and the College of Food Science and Nutritional Engineering of the China Agricultural University in Beijing, Unilever drafts the Food Safety Report of China annually. Having established a professional brand image, Unilever also provides consulting services to local food firms, restaurants, and hotels, helping design solutions related to environmental-friendly food supply and sustainable sourcing.

\subsubsection{Differences between the Cases}

It is also noted that firms respond to institutional pressure differently according to their backgrounds. For example, although Landsea actively forms industrial networks to exert its influence, such influence is mainly targeted at customers and industrial peers. Landsea as an indigenous has more knowledge about and is more sensitive to the localized customer expectation for innovative products. Therefore, Landsea is able to identify nonconformity in institutions. However, as the government always plays a dominant role in China, a private firm such as Landsea could hardly bring direct influence on institution regarding sustainability. This finding is consistent to Chen [39]'s finding: 
small and medium enterprises (SMEs) are more likely to initiative green investments proactively rather than in response to institutions to enhance their sustainability innovation capability and green image. The research findings also show that local firms in the emerging market prioritize building reputation as a strategic objective early in its development, and being green can be a differentiation and reputation building strategy. For indigenous SMEs, such as Landsea, filling an institutional void is inherently complicated and resource-demanding, and getting a strong or reputable alliance to commit to a partnership is difficult (as it needs an agreement where both parties have aligned incentives). Therefore, Landsea's strategic respond to institutional constraints is more to focus their resources on non-conformity and make cumulative effect of localizing international green designs and technologies to meet current customer expectations.

In comparison, MNCs in this study are play a more influential role in the development of institution. Especially in terms of institutional void regarding sustainability, MNCs bring world-class practices and standards into China's market. Green innovation projects are launched in China market and initiated from MNCs' global sustainability plans and standards. The sufficient resources, experiences in global markets and the know-how of MNCs not only set an example for industrial peers, but also were able to influence the institutionalization of China's corporate sustainability. The study also finds evidence that government officials from Central Government have received education courses about environmental protection and sustainability with the help of MNCs. In addition, their green innovation design and production process are standardized under global norms, while the diffusion process (including organizational communication and market advertising) is localized to meet Chinese local expectations. The differences of firms' green innovation and their strategic responses to institutional constraints are summarized in Table 5.

Table 5. Differences of firms' green innovations and strategic responses to institutional constraints.

\begin{tabular}{ccc}
\hline & Green Innovation Features & Strategic Responses \\
\hline $\begin{array}{c}\text { MNCs (GE, } \\
\text { Philips, Mary Kay) }\end{array}$ & Innovation initiatives & Engaging and enacting with global standards \\
\cline { 2 - 3 } & $\begin{array}{c}\text { Innovation } \\
\text { resources/capabilities }\end{array}$ & Changing and influencing the industrial norms \\
\cline { 2 - 3 } $\begin{array}{c}\text { Indigenous SMEs } \\
\text { (Landsea) }\end{array}$ & Innovation design & Standardized design, localized communication and advertising \\
\cline { 2 - 3 } & Innovation initiatives & Building reputation and differentiation \\
\hline
\end{tabular}

\section{Towards a Generalized Model for Corporate Sustainability in an Emerging Economy}

\subsection{Conceptual Framework}

Based on the analyses of firms' innovative strategies in their green innovation projects, a framework can be developed (Figure 3). The conceptual framework illustrates the process of firms conducting their green innovation projects, while interacting with their institutional environment. We focus on the specific institutional setting of an immature economic system:

Proposition 1. In an emerging economy system with nonconformity and void in corporate sustainability supportive institutional contexts, enterprises employ appropriate innovation with multi-forms of strategy to drive business and profitability.

Strategically, sustainability is the representation of strategic responses, i.e., it is the direct goal of innovative organizational behavior. For long-run business operation, sustainability can enhance the profitability of an enterprise. It can drive business growth, dominate upstream and downstream value chains, trigger innovation in $\mathrm{R} \& \mathrm{D}$, develop markets in virgin territory, and inspire high-quality employees (Table 3, quote B2-3). 


\subsection{Institutional Push to Organizations}

Corporate sustainability can be seen as the result of institutional negotiation conducted by motivated actors with insufficient institutional resources or support [46,47]. For maintaining their sustainability strategy and green innovative projects under the pressure of isomorphism, firms should first be familiar with or embed themselves in the institutional logics; based on that, firms need to be able to leverage and mobilize support for their innovative sustainability practices from very different actors and constituencies with their agency actions. Actions and ideas adapted for green innovation products need to be consistent with established practices and expectations in the market, and fit better into established customer norms. Thus, we propose the following Lemma 1 to describe the initial part of the framework.

Lemma 1. In an emerging economy context, corporate sustainability and green innovation can be driven by the interaction between sustainability-related institutional void and nonconformity, and the strategic responses and corporate proactivity of organizations with respect to the institutional context.

Organizations, as social actors, first must identify the institutional characteristics which influence their sustainability projects and adoption via context. Then, with corporate resources, such as corporate reputation, sustainability culture, and new products experiences, organizations can proactively seek institutional support in the local context. Thus, to a certain degree, we see a dynamic co-evolution mechanism in the interface between institutions and organizations.

\subsection{Strategic Responses}

By studying the drivers, learning and design process, and design characteristics, common institutional negotiation strategies have been identified for firms to use when interacting with the external institutional environment: localizing and adapting, engaging and enacting. These strategies of responding and adapting to institutional contexts reflect firms' abilities to leverage their resources to help negotiate and reshape the institutional environment. Firms' strategic responses are not independent but interdependent with each other: the localizing and adapting strategy for overcoming innovation barriers cannot be achieved without engaging multiple stakeholders and enacting new norms together with them. Based on this fundamental concept, we introduce Lemma 2, which constitutes the main body in Figure 3:

Lemma 2. In an emerging economy context with the presence of sustainability-related institutional void and nonconformity, organizations can apply localizing and adapting, engaging and enacting strategies to deepen connections with the local external environment and create synergies through those connections.

Localizing and adapting are basic requirements for firms in a new market. As the empirical evidence above reveals, the firms are stimulated to engage in/develop localized green innovations. New ideas and designs aiming to adapt to local regulations, norms and cognitions are applied to the products launched in the local market.

Engaged relationships or networks with stakeholders can provide a platform for the aspiring innovating firms to understand the institutional context. A strategy of engagement alone is insufficient if a firm intends to diversify and dominate new areas in an emerging economy; thus, engagement must be coupled with enactment. Engaging and enacting is an active strategy that should occur when a firm gains sufficient dominance in one sector and intends to integrate upstream and downstream: it helps the innovating actors to disseminate their norms and logics for sustainability. By engaging with stakeholders, innovating firms can set up norms and gain knowledge for localizing their sustainability innovations. This can be seen as an institutional negotiation method of using inputs by actors from different domains. Macroscopically, this series of proactive strategic responses will generate a counterforce back to the institution itself. 
Lemma 3. In an emerging economy system with nonconformity and void in corporate sustainability supportive institutional contexts, corporate sustainability can enhance long-run profitability.

Enterprises are profit-oriented intrinsically, and all of their sustainability-related innovations are aimed at profitability in the long-run. Although CSR and Stakeholder Theory are often used as platitudes to satisfy outside observers, the nature of firms are profit-oriented organizations. Our study shows that firms' green innovation projects can be strategically critical endeavors with long-term profitability goals.

\section{Discussion and Conclusions}

We draw on institutional theory and propose a new theoretical framework for researching innovating firms' practices towards sustainability in an emerging economy context. The research setting is firms operating in China, because its distinctive institutional environment creates an ideal situation to examine the pressures related to corporate sustainability. Green innovation projects launched in the market were selected to examine how the corporate sustainability initiative was implemented and innovative design contextualized. Based on insights obtained from both archival documents and in-depth interviews with top executives from four large exemplary firms, and firms' stakeholders in green innovation projects, we identify the relevant institutional factors and the firms' corresponding responses. Although government has turned its attention towards sustainability, we find that supporting institutions are still largely lagging behind or absent. However, such institutional void poses both barriers and opportunity spaces for motivated and innovating actors. The connections between strategic responses and institutional constraints uncovered in our study are also depended on the aspirations of actors, in addition to organizational resources. Actors in our study were primarily concerned with leveraging sustainability into competitive advantages of organizations. For them, institutional voids and nonconformities are not only constraints, but also opportunities to select a corner of the institutional context more supportive of their innovation. For example, being green can be a differentiation branding strategy for local SMEs, while the voids can be turned into means for MNCs to build up their influences and networks. To environmental uncertainty, our findings suggest that ambiguity provides opportunities for transformation. Innovating actors in green innovation projects do not seek to avoid uncertainty, but rather to identify and exploit it.

In most cases, the Chinese government plays a dominant role in institutional development. Progress in sustainability was pushed by the Chinese government via state-directed projects, development of political concepts, legislation, etc. Under these circumstances, it does not mean that other players have no opportunity to shape the institutional landscape and marketplace with respect to sustainability. In firms' strategic proactivity towards sustainability projects, opportunity and interaction are central to their innovating practices. Our research results show that institutional barriers and institutional void also provide opportunities for innovating firms to infuse new beliefs, norms and values into their stakeholders such as business partners and the local government. In responding to institutional barriers, innovating firms usually start with a clear objective, and achieve it via continuous interaction with the exterior environment. Thus, opportunities can be created via interaction at the organization-environment interface. In addition, new institutional arrangements can be crafted by taking advantage of institutional void and negotiating sustainability into corporate norms and practices.

In such an institutional setting, firms are always in the state of passive illegitimacy. In order to gain legitimacy, companies first need to learn and address the special characteristics of the institutional context, i.e., become embedded in the institutional context. In addition, this study confirms that the institutions for sustainability are weak and largely absent in China; therefore, in the case of green innovation processes in China, "legitimacy crises" originate more from the institutional void than from conflict within well-established institutions. 
The localization and embedding are strategies of firms conducting sustainability in a challenging and non-enabling institutional context. Facing institutional void, firms can choose other non-sustainability strategies, such as large multinationals' environmental protection practices reducing to a lower standard or any other non-sustainability practices in a developing context [63]. It is also expected that multinationals exert their influence and know-how to shape the institutional field formation [31], instead of solely embedding into local standards and norms. The above responses are in contrast with localization and embedding in case firms' sustainability strategies. In the meantime, that localization and embedding took place, leading firms also proactively enacted and formed new institutional field in terms of sustainability. These strategies are not categorized different or applied in different stages, but are adopted responsively based on the firms' specific green innovation projects. Put another way, leading firms in an institutional void context cannot be distinguished as either "filed maker" who takes the initiative in defining the issues and facilitating the emergence of a field (e.g., corporate sustainability practices and standards), or "filed taker" who complies with the existing norms of authority and expectation of consumers. In the economic political context of China, firms need to develop "negotiation capability" and play the role of institutional entrepreneur developing/changing the institution while negotiating with it.

This research contributes to theory development in three aspects. Firstly, the empirical findings explain the phenomenon of corporate sustainability practices that not only meet, but also exceed, local institutional standards. The proactivity in firms' green innovation enriched research in organization responding to institutional pressure $[60,64]$. Secondly, in addition to existing studies that investigated the institutional pressure and how organizations respond in their innovation projects within organizational context [75,76], our study further investigated the interaction between organization and institutional context. During such a process, it is found that firms gain legitimacy not only through isomorphism but also active enactment and engagement. This is consistent with literature of International Business: firms not only are in a passive position coping with rapidly changing and often chaotic environment, but also can proactively build legitimacy to enhance their long-term growth prospects $[29,30,72]$. Thirdly, this study contributes to literature of corporate sustainability strategy. While previous research in this field mainly focuses on evaluating the drivers, criteria and effectuation of corporate sustainability $[38,39,103-105]$, this study further examines the strategic initiatives of corporate sustainability and presents a localization process of green innovation. A conceptual model centered on corporate negotiation capability is also developed.

\subsection{Managerial Implications}

This study investigates the process and localization of corporate sustainability and green innovation projects. Research findings help MNCs better understand the specific Chinese institutional features regarding corporate sustainability. It suggests that high end technologies or the newness in green innovation are not necessary the success factors, instead, new products design need to consider contextual expectations, as well as engage, enact and educate new norms. The study also provides suggestions for Chinese local firms embracing sustainability strategy and conduct environmentally friendly products innovation. Studied firms show that green innovation with localized features not only obtained new business development opportunities but also leverage such green innovation projects into business legitimacy, and develop further influence on local industrial standards.

It is found that the "negotiation capability" is essential for firms to successfully localize their corporate initiatives and development of green innovation products. This implies that firms facing immature institutions not only need to familiarize themselves with local expectations, but also need to decide which institutional void and nonconformities can be leveraged and turned into opportunities through strategic responses.

Specifically, in the localizing and adapting strategy, because the Central Government plays an essential role in the construction of the regulatory pillars for the development of sustainability markets, companies conducting innovation projects put much importance on government policies 
and regulations regarding environmental protection and sustainability. Under the government-led institutional environment, innovating firms also actively search for the institutional jumping-off point to maximize their impact on policies and regulations. In this way, it can be expected that firms leading sustainability initiatives can be more accepted or legitimated by government and their green innovation processes can proceed.

Furthermore, in order to address the triple bottom line as well as to seek conformance with the institutional logics (especially the normative and cognitive pillars), firms as embedded actors develop their innovation capabilities which not only address the factor of sustainability, but more importantly, the factor of functionality. The sustainability factor needs to be localized also because the sustainability standards/expectations are different from the standards of developed economies. For example, Landsea did not directly implant the green design from advanced economies or solely focus on environmental protection features of its products, instead, the expectation of consumers from local market (e.g., purified air, constant temperature living environment) was met by Landsea's localized housing products.

To engage with customers and to diffuse green innovation features, innovating firms need to pay attention to the details of their design to educate the public regarding the technical features and the social structure of existing supporting systems. Purely novel actions and ideas cannot diffuse well because no established logics exist to describe them. Without invoking existing understanding, innovations may never be understood and adopted in the first place. Success, then, requires entrepreneurs to locate their ideas within the set of understandings and patterns of action that constitute the institutional environment in order to gain initial acceptance, yet somehow retain the inherent differences in the new technology that ultimately will be needed to change those institutions. Thus, to strike a balance, prospective innovators must carefully choose designs that include some familiar features, present others as new, and keep still others hidden from view.

We find that in order to effectively recombine firms' resources to achieve a long-term goal (in sustainability), sustainability is always integrated into firms' strategy, especially a differentiation strategy or for first-mover advantage. A clear vision towards sustainability as well as consistent and strong organizational support is critical for successful green innovation projects. For example, Unilever had launched the "Sustainability Living Plan" as an organizational dialogue platform on which organizational members from different departments can exchange their ideas and experiences for better practices towards sustainability. Besides, the process of green innovation implementation needs support from an ecosystem of a company, as an openness to firms' external partners will help them to obtain understandings of the local context and customer need.

\subsection{Limitation and Future Research}

Our findings raise challenging issues for managing corporate sustainability and green innovation. The sustainability projects investigated are conducted by experienced organizations with espoused commitments to R\&D and dedication to sustainability development. Our research suggests that corporate sustainability can only be part of the solution to enable sustainability development, and it is necessary to be complemented by the agency of other social actors. In addition, firms' green innovations are mostly of the category of incremental innovation, and innovation based on radical ideas or breakthrough technologies might face greater challenges in their innovation process, and thus need further investigation.

A further limitation of this study is that it is largely retrospective, which might constrain the accuracy and completeness of data, in particular on reflective processes from the earlier stages of the innovation histories. Real-time investigation of sustainability development trajectories can extend the present study by exploring how strategic responses are crafted over time and how the firms negotiate with both internal and external environments. Moreover, future direction can focus on failed projects and unsuccessful attempts in sustainability projects, and provide complementary theoretical insight. 
Our study has shown that MNCs play a more influential role in the development of institution. Especially in terms of institutional void regarding sustainability, MNCs bring world-class practices and standards into China's market. The sufficient resources, experiences in global markets and the know-how of MNCs not only set an example for industrial peers, but also were able to influence the institutionalization of China's corporate sustainability. Such an institutionalization process, although important, is not the focus of this study. Future research could investigate the dynamic process among different stakeholders in a longitudinal perspective.

In addition, as this study mainly investigates the localization and interaction between companies and institutional environment within one country, future studies with a comparative perspective can extend the investigation on different types of organizations (MNCs and local firms) conducting their green innovation projects with varying resources and strategic initiatives. Similarly, a cross-cultural perspective can identify how corporate sustainability and green innovation process from developing and developed countries differ from each other, and how firms from different industrial backgrounds conduct sustainability differently. Moreover, this study focusing on firms responding to institutional challenges does not provide an overall insight to the development of institutions of corporate sustainability. Future studies can focus on the institutionalization process and the role of institutional entrepreneurship in a changing institutional field [106,107]. Finally, as this study provides a conceptual framework, its propositions can be further tested with a deductive approach and quantitative research methods.

Author Contributions: This paper received individual contribution of each author as specified: the first author developed the conceptual framework and conducted fieldwork. The second author provided complementary perspectives in theory and practice, reviewed the case study and revised the manuscript. All authors read the full paper and agreed with its publication.

Funding: Part of this study were financially supported by the Ministry of Science and Technology in Taiwan.

Acknowledgments: The authors would like to acknowledge the professionals who collaborated during this study.

Conflicts of Interest: The authors declare no conflict of interest.

\section{References}

1. Elkington, J. Cannibals with Forks: The Triple Bottom Line of 21st Century Business; Capstone: Oxford, UK, 1997.

2. Lubin, D.A.; Esty, D.C. The sustainability imperative. Harv. Bus. Rev. 2010, 88, 42-50.

3. Nicholls, A. Social Entrepreneurship: New Models of Sustainable Social Change; Oxford University Press: Cary, NC, USA, 2006.

4. Wüstenhagen, R.; Hamschmidt, J.; Sharma, S.; Starik, M. Sustainable Innovation and Entrepreneurship; Elgar: Cheltenham, UK, 2008.

5. Wüstenhagen, R.; Bilharz, M. Green energy market development in Germany: Effective public policy and emerging customer demand. Energy Policy 2006, 34, 1681-1696. [CrossRef]

6. Chesbrough, H.W. Open Innovation: The New Imperative for Creating and Profiting from Technology; Harvard Business Press: Brighton, MA, USA, 2003.

7. Tani, M.; Papaluca, O.; Sasso, P. The system thinking perspective in the open-innovation research: A systematic review. J. Open Innov. Technol. Market Complex. 2018, 43, 38. [CrossRef]

8. Gupta, S.; Kumar, V. Sustainability as corporate culture of a brand for superior performance. J. World Bus. 2013, 48, 311-320. [CrossRef]

9. Gupta, S.; Czinkota, M.; Melewar, T.C. Embedding knowledge and value of a brand into sustainability for differentiation. J. World Bus. 2013, 48, 287-296. [CrossRef]

10. Slaper, T.F.; Hall, T.J. The Triple Bottom Line: What Is It and How Does It Work? Indiana Bus. Rev. 2011, $86,4-8$.

11. Christiansen, A.C.; Buen, J. Managing environmental innovation in the energy sector: The case of photovoltaic and wave power development in Norway. Int. J. Innov. Manag. 2002, 6, 233-256. [CrossRef]

12. Adamczyk, S.; Hansen, E.G.; Reichwald, R. Measuring Sustainability by Environmental Innovativeness: Results from Action Research at a Multinational Corporation in Germany. In Proceedings of the International 
Conference and Doctoral Consortium on Evaluation Metrics of Corporate Social and Environmental Responsibility, Lyon, France, 8-10 June 2009.

13. Ma, Y.; Yin, Q.; Pan, Y.; Cui, W.; Xin, B.; Rao, Z. Green product innovation and firm performance: Assessing the moderating effect of novelty-centered and efficiency-centered business model design. Sustainability 2018, 10, 1843. [CrossRef]

14. Golicic, S.L.; Smith, C.D. A Meta-Analysis of Environmentally Sustainable Supply Chain Management Practices and Firm Performance. J. Supply Chain Manag. 2013, 49, 78-95. [CrossRef]

15. Shrivastava, P. The role of corporations in achieving ecological sustainability. Acad. Manag. Rev. 1995, 20, 936-961. [CrossRef]

16. Shrivastava, P. Environmental technologies and competitive advantage. Strateg. Manag. J. 1995, 16, $183-201$. [CrossRef]

17. Yan, M.; Chien, K.; Yang, T. Green component procurement collaboration for improving supply chain management in the high technology industries: A case study from the systems perspective. Sustainability 2016, 8, 105. [CrossRef]

18. Yan, M. Project-based market competition and policy implications for sustainable developments in building and construction sectors. Sustainability 2015, 7, 15423-15448. [CrossRef]

19. Ameer, R.; Othman, R. Sustainability practices and corporate financial performance: A study based on the top global corporations. J. Bus. Ethics 2012, 108, 61-79. [CrossRef]

20. Delmas, M.A.; Pekovic, S. Corporate Sustainable Innovation and Employee Behavior. J. Bus. Ethics 2016, 150, 1071-1088. [CrossRef]

21. Planko, J.; Cramer, J.M.; Chappin, M.M.; Hekkert, M.P. Strategic collective system building to commercialize sustainability innovations. J. Clean. Prod. 2016, 112, 2328-2341. [CrossRef]

22. Rao, P.; Holt, D. Do Green Supply Chains Lead to Economic Performance? Int. J. Oper. Prod. Manag. 2005, 25, 898-916. [CrossRef]

23. Rezaee, Z. Supply chain management and business sustainability synergy: A theoretical and integrated perspective. Sustainability 2018, 10, 275. [CrossRef]

24. Weiser, J.; Zadek, S. Conversations with Disbelievers; Ford Foundation: New York, NY, USA, 2000.

25. Day, R.M. Beyond Eco-Efficiency: Sustainability as a Driver for Innovation; World Resources Institute Sustainable Enterprise Initiative: Washington, DC, USA, 1998.

26. Hart, S.L. Beyond greening: Strategies for a sustainable world. Harv. Bus. Rev. 1997, 75, 67-76.

27. Prahalad, C.K.; Hammond, A. Serving the world's poor, profitably. Harv. Bus. Rev. 2002, 80, 48-57. [PubMed]

28. Prahalad, C.K.; Hart, S.L. Strategies for the Bottom of the Pyramid: Creating Sustainable Development; University of Michigan Press: Ann Arbor, MI, USA, 1999.

29. Ahlstrom, D.; Bruton, G.D.; Lui, S.S. Navigating China's changing economy: Strategies for private firms. Bus. Horiz. 2000, 43, 5-15. [CrossRef]

30. Ahlstrom, D.; Bruton, G.D.; Yeh, K.S. Private firms in China: Building legitimacy in an emerging economy. J. World Bus. 2008, 43, 385-399. [CrossRef]

31. Child, J.; Tsai, T. The dynamic between firms' environmental strategies and institutional constraints in emerging economies: Evidence from China and Taiwan. J. Manag. Stud. 2005, 42, 95-125. [CrossRef]

32. Baum, J.A.C.; Oliver, C. Institutional Embeddedness and the Dynamics of Organizational Populations. Am. Sociol. Rev. 1992, 57, 540-559. [CrossRef]

33. Oliver, C. Strategic responses to institutional processes. Acad. Manag. Rev. 1991, 16, 145-179. [CrossRef]

34. Oliver, C. Sustainable competitive advantage. Strateg. Manag. J. 1997, 18, 697-713. [CrossRef]

35. Harriss, J.; Hunter, J.; Lewis, C.M. (Eds.) The New Institutional Economics and Third World Development; Routledge: London, UK, 1995.

36. Meyer, J.W.; Rowan, B. Institutional organizations: Formal structure as myth and ceremony. Am. J. Sociol. 1977, 83, 340-363. [CrossRef]

37. Scott, W.R. Institutions and Organizations; Sage: Thousand Oaks, CA, USA, 2001.

38. Hoogendoorn, B.; Guerra, D.; van der Zwan, P. What drives environmental practices of SMEs? Small Bus. Econ. 2015, 44, 759-781. [CrossRef]

39. Chen, Y.S. The driver of green innovation and green image-Green core competence. J. Bus. Ethics 2008, 81, 531-543. [CrossRef] 
40. Kai, H.; Wüstenhagen, R. Greening Goliaths versus emerging Davids-Theorizing about the role of incumbents and new entrants in sustainable entrepreneurship. J. Bus. Ventur. 2010, 25, 481-492.

41. Zailani, S.; Govindan, K.; Iramanesh, M.; Shaharudin, M.R.; Chong, Y.S. Green innovation adoption in automotive supply chain: The Malaysia case. J. Clean. Prod. 2015, 108, 1115-1122. [CrossRef]

42. Poisson-de Haro, S.; Bitektine, A. Global sustainability pressures and strategic choice: The role of firms' structures and non-market capabilities in selection and implementation of sustainability initiatives. J. World Bus. 2015, 50, 326-341. [CrossRef]

43. Cantwell, J.; Dunning, J.H.; Lundan, S.M. An evolutionary approach to understanding international business activity: The co-evolution of MNEs and the institutional environment. J. Int. Bus. Stud. 2010, 41, 567-586. [CrossRef]

44. Strauss, A.; Corbin, J. Basics of Qualitative Research: Techniques and Procedures for Developing Grounded Theory; Sage: Thousand Oaks, CA, USA, 1998.

45. Strauss, A. Qualitative Analysis of Social Scientists; Cambridge University Press: Cambridge, UK, 1987.

46. Baker, T.; Nelson, R.E. Creating something from nothing: Resource construction through entrepreneurial bricolage. Adm. Sci. Q. 2005, 50, 329-366. [CrossRef]

47. Battilana, J.; Leca, B.; Boxenbaum, E. How actors change institutions: Towards a theory of institutional entrepreneurship. Acad. Manag. Ann. 2009, 3, 65-107. [CrossRef]

48. Shu, C.; Zhou, K.Z.; Xiao, Y.; Gao, S. How green management influences product innovation in China: The role of institutional benefits. J. Bus. Ethics 2016, 133, 471-485. [CrossRef]

49. Cruz, N.; Marques, R. Scorecards for sustainable local governments. Cities 2014, 39, 165-170. [CrossRef]

50. Rezaee, Z. Corporate sustainability: Theoretical and integrated strategic imperative and pragmatic approach. J. Bus. Inq. 2017, 16, 60-87.

51. Bartlett, D.; Trifilova, A. Green technology and eco-innovation: Seven case-studies from a Russian manufacturing context. J. Manuf. Technol. Manag. 2010, 21, 910-929. [CrossRef]

52. Kemp, R.; Pearson, P. Final Report of the MEI Project Measuring Eco Innovation. UM Merit Maastricht. 2007. Available online: http:/ / www.merit.unu.edu/MEI/deliverables/MEI\%20D15\%20Final\%20report\% 20about\%20measuring\%20eco-innovation.pdf (accessed on 20 July 2015).

53. Kim, T. Identifying Stakeholders and Interactions in the Dementia Café in Seongju through Empathic Service Design Approaches. J. Open Innov. Technol. Mark. Complex. 2018, 4, 28. [CrossRef]

54. Gupta, A.; Dey, A.; Shinde, C.; Mahanta, H.; Patel, C.; Ratel, R.; Sahay, N.; Sahu, B.; Vivekanandan, P.; Verma, S.; et al. Theory of open inclusive innovation for reciprocal, responsive and respectful outcomes: Coping creatively with climatic and institutional risks. J. Open Innov. Technol. Mark. Complex. 2016, 2, 16. [CrossRef]

55. Schiuma, G.; Carlucci, D. Managing Strategic Partnerships with Universities in Innovation Ecosystems: A Research Agenda. J. Open Innov. Technol. Mark. Complex. 2018, 4, 25. [CrossRef]

56. Yun, J.J.; Jeon, J.; Park, K.; Zhao, X. Benefits and Costs of Closed Innovation Strategy: Analysis of Samsung's Galaxy Note 7 Explosion and Withdrawal Scandal. J. Open Innov. Technol. Mark. Complex. 2018, 4, 20. [CrossRef]

57. Campbell, J.L. Why should corporations behave in socially responsible ways? Acad. Manag. Rev. 2007, 26, 22-40.

58. Doh, J.P.; Guay, T.R. Corporate social responsibility, public policy, and NGO activism in Europe and the United States: An institutional-stakeholder perspective. J. Manag. Stud. 2006, 43, 47-73. [CrossRef]

59. Gardberg, N.A.; Fombrun, C.J. Corporate citizenship: Creating intangible assets across institutional environments. Acad. Manag. Rev. 2006, 31, 329-346. [CrossRef]

60. Marquis, C.; Glynn, M.A.; Davis, G.F. Community isomorphism and corporate social action. Acad. Manag. Rev. 2007, 32, 925-945. [CrossRef]

61. Matten, D.; Moon, J. 'Implicit' and 'Explicit' CSR: A conceptual framework for a comparative understanding of corporate social responsibility. Acad. Manag. Rev. 2008, 33, 404-424. [CrossRef]

62. Weller, R. Discovering Nature: Globalization and Environmental Culture in China and Taiwan; Cambridge University Press: Cambridge, UK, 2006.

63. Levinson, A.; Scott, T. Unmasking the Pollution Haven Effect. Int. Econ. Rev. 2008, 49, 223-254. [CrossRef]

64. North, D.C. Institutions, Institutional Change and Economic Performance; Cambridge University Press: Cambridge, UK, 1990. 
65. Child, J. Organizational structure, environment and performance: The role of strategic choice. Sociology 1972, 6, 1-22. [CrossRef]

66. Easterbrook, G. A Moment on the Earth; Viking: New York, NY, USA, 1995.

67. Tenbrunsel, A.; Wade-Benzoni, K.; Messick, D.; Bazerman, M. The dysfunctional effects of standards on environmental attitudes and choices. In Psychological Perspectives to Environmental and Ethical Issues; Bazerman, M., Messick, D., Tenbrunsel, A., Wade-Benzoni, K., Eds.; New Lexington Books: San Francisco, CA, USA, 1997; pp. 105-121.

68. Liu, Y. High-tech ventures' innovation and influences of institutional void: A comparative study of two high-tech parks in china. J. Chin. Entrep. 2008, 3, 112-133. [CrossRef]

69. Child, J. Strategic choice in the analysis of action, structure, organizations and environment: Retrospect and prospect. Organ. Stud. 1997, 18, 43-76. [CrossRef]

70. Young, M.N.; Tsai, T.; Wang, X.; Liu, S.; Ahlstrom, D. Strategy in Emerging Economies and the Theory of the Firm. Asia Pac. J. Manag. 2014, 31, 331-354. [CrossRef]

71. Berrone, P.; Fosfuri, A.; Gelabert, L.; Gomez-Mejia, L.R. Necessity as the mother of 'green'inventions: Institutional pressures and environmental innovations. Strateg. Manag. J. 2013, 34, 891-909. [CrossRef]

72. Ahlstrom, D.; Levitas, E.; Hitt, M.A.; Dacin, M.T.; Zhu, H. The three faces of China: Strategic alliance partner selection in three ethnic Chinese economies. J. World Bus. 2014, 49, 572-585. [CrossRef]

73. Aldrich, H.; Fiol, M. Fools rush in? The institutional context of industry creation. Acad. Manag. Rev. 1994, 19, 645-669. [CrossRef]

74. Dougherty, D.; Heller, T. The illegitimacy of successful product innovation in established firms. Organ. Sci. 1994, 5, 200-218. [CrossRef]

75. Dijk, S.V.; Berends, H.; Jelinek, M.; Romme, G.L.; Weggeman, M. Micro-institutional affordances and strategies of radical innovation. Organ. Stud. 2011, 32, 1485-1513. [CrossRef]

76. Garud, R.; Karnøe, P. Bricolage vs. breakthrough: Distributed embedded agency in technology entrepreneurship. Res. Policy 2003, 32, 277-300. [CrossRef]

77. Sorli, M.; Stokic, D. Innovating in Product/Process Development: Gaining Pace in New Product Development; Springer Science \& Business Media: Berlin, Germany, 2009.

78. Shane, S. Prior knowledge and the discovery of entrepreneurial opportunities. Organ. Sci. 2000, 11, 448-467. [CrossRef]

79. Khanna, T.; Palepu, K. The future of business groups in emerging markets: Long-run evidence from Chile. Acad. Manag. J. 2000, 43, 268-285.

80. Rao, H.; Morrill, C.; Zald, M.N. Power plays: How social movements and collective action create new organizational forms. Res. Organ. Behav. 2000, 22, 239-247. [CrossRef]

81. Miller, D.; Lee, J.; Chang, S.; Le Breton-Miller, I. Filling the institutional voids: The social behavior and performance of family vs non-family technology firms in emerging markets. J. Int. Bus. Stud. 2009, 40, 802-817. [CrossRef]

82. Beckert, J. Beyond the Market: The Social Foundations of Economic Efficiency; Princeton University Press: Princeton, NJ, USA, 2002.

83. Douglas, M. How Institutions Think; Syracuse University Press: Syracuse, NY, USA, 1986.

84. Lawrence, T.B.; Phillips, N. From Moby Dick to Free Willy: Institutional entrepreneurship in emerging institutional fields. Organization 2003, 11, 689-711. [CrossRef]

85. Schumpeter, J.A. The Theory of Economic Development: An Inquiry into Profits, Capital, Credit, Interest and the Business Cycle; Harvard University Press: Cambridge, MA, USA, 1934.

86. Swidler, A. Culture in action: Symbols and strategies. Am. Sociol. Rev. 1986, 51, 273-286. [CrossRef]

87. Gioia, D.A.; Corley, K.G.; Hamilton, A.L. Seeking qualitative rigor in inductive research: Notes on the Gioia methodology. Organ. Res. Methods 2013, 16, 15-31. [CrossRef]

88. Vaughan, D. Theory elaboration: The heuristics of case analysis. In What Is a Case? Exploring the Foundations of Social Inquiry; Ragin, C., Becker, H.S., Eds.; Cambridge University Press: Cambridge, UK, 1992; pp. 173-202.

89. Eisenhardt, K. Building theories from case study research. Acad. Manag. Rev. 1989, 14, 532-550. [CrossRef]

90. Locke, K. Grounded Theory in Management Research; Sage Publication: London, UK, 2001.

91. CARTER, N.; MOL, A.P. Environmental governance in China; Routledge: Abingdon, UK, 2013.

92. Sinkule, B.J.; Ortolano, L. Implementing Environmental Policy in China; Greenwood Publishing Group: Westport, CT, USA, 1995. 
93. Flick, U. An introduction to Qualitative Research; Sage: Thousand Oaks, CA, USA, 2009.

94. Patton, M.Q. Qualitative Research and Evaluation Methods; Sage: Thousand Oaks, CA, USA, 2002.

95. Silverman, D.; Marvasti, A. Doing Qualitative Research. A Compressive Guide; Sage: Thousand Oaks, CA, USA, 2008.

96. Bain, W. China's environment: A different game. Manag. Rev. 1998, 87, 43-47.

97. Zhang, W.; Vertinsky, I.; Ursachi, T.; Nemetz, P. Can China be a clean tiger? Growth strategies and environmental realities. Pac. Aff. 1999, 7, 23-37. [CrossRef]

98. Dean, J.M.; Lovely, M.E.; Wang, H. Are foreign investors attracted to weak environmental regulations? Evaluating the evidence from China. J. Dev. Econ. 2009, 90, 1-13. [CrossRef]

99. Miles, S. Stakeholders: Essentially contested or just confused? J. Bus. Ethics 2012, 108, 285-298. [CrossRef]

100. Driessen, P.H.; Hillebrand, B. Integrating multiple stakeholder issues in new product development: An exploration. J. Prod. Innov. Manag. 2013, 30, 364-379. [CrossRef]

101. Hartman, C.L.; Hofman, P.S.; Stafford, E.R. Partnerships: A path to sustainability. Bus. Strategy Environ. 2002, 8, 255-266. [CrossRef]

102. Siebenhüner, B.; Arnold, M. Organizational learning to manage sustainable development. Bus. Strategy Environ. 2007, 16, 339-353. [CrossRef]

103. Dangelico, R.M.; Pujari, D. Mainstreaming green product innovation: Why and how companies integrate environmental sustainability. J. Bus. Ethics 2010, 95, 471-486. [CrossRef]

104. Totterdell, P.; Leach, D.; Birdi, K.; Clegg, C.; Wall, T. An investigation of the contents and consequences of major organizational innovations. Int. J. Innov. Manag. 2002, 6, 343-368. [CrossRef]

105. Wagner, M.; Llerena, P. Drivers for Sustainability-Related Innovation: A Qualitative Analysis of Renewable Resources, Industrial Products and Travel Services; No. 2008-22; Bureau d’Economie Théorique et Appliquée, UDS: Strasbourg, France, 2008.

106. Delmestri, G.; Greenwood, R. How Cinderella became a queen: Theorizing radical status change. Adm. Sci. $Q$. 2016, 61, 507-550. [CrossRef]

107. Greenwood, R.; Suddaby, R. Institutional entrepreneurship in mature fields: The Big Five accounting firms. Acad. Manag. J. 2006, 49, 27-48. [CrossRef]

(C) 2018 by the authors. Licensee MDPI, Basel, Switzerland. This article is an open access article distributed under the terms and conditions of the Creative Commons Attribution (CC BY) license (http:/ / creativecommons.org/licenses/by/4.0/). 